\title{
Magnum miraculum est homo.... The Phenomenon of Man in the Light of Hermetic Excerpts: Lactantius, Div. inst. 7.13.3
}

\author{
AGATA SOWIŃSKA \\ Faculty of Humanities, University of Silesia in Katowice \\ e-mail: agata.ewa.sowinska@gmail.com \\ ORCID: 0000-0002-3399-3200
}

\begin{abstract}
The aim of this paper is to present the question of human nature in a hermetic approach based on the source texts of Asclepius and Corpus Hermeticum. As the reference point for a research on hermetic anthropology serves one of the hermetic fragments found in Lactantius' Divinae institutiones (i.e. Div. inst. 7.13.3), who focused on a characteristic feature of every human being: their dual nature - both divine and hylic. The analysis of Div. inst. 7.13.3 is preceded by a short study, based on the anthology by M.D. Litwa, of the range of influence of hermetic texts on literature from antiquity to the Middle Ages.
\end{abstract}

Keywords: Asclepius, Corpus Hermeticum, hermetic literature, Hermetism, hermetic anthropology, Lactantius, Divinae institutiones, hermetic testimonies, hermetic fragments

\section{Introduction. The legend of Hermes Trismegistus - The Range of Influence: Hermetic testimonia and fragmenta from Various Authors (A Review of Sources Based on Litwa's Anthology)}

Hermetism $^{1}$ is a phenomenon associated with the figure of Hermes Thrice Great/"Hermes Thrice Greatest" (Hermes Trismegistus), and it dates back in its origin to ancient Egypt, and, more specifically, to the Egyptian Alexandria; hence, to a place constituting at the time an authentic cultural melting pot. Due to the thematic scope of texts attributed to Trismegistus, the contemporary research on hermetic literature has introduced a division between philosophical and religious hermetic texts, as the foundation of the so-called philosophical/learned

\footnotetext{
"Hermetism" vs. "Hermeticism," see, among others: R. van den Broek, "Gnosticism and Hermetism in Antiquity. Two Roads to Salvation," Gnosis and Hermeticism. From Antiquity to Modern Times (eds. R. van den Broek - W.J. Hanegraaff) (Albany, NY: State University of New York 1998) 5-6; A. Faivre, "Renaissance Hermeticism and the Concept of Western Esotericism," Gnosis and Hermeticism. From Antiquity to Modern Times (eds. R. van den Broek - W.J. Hanegraaff) (Albany, NY: State University of New York 1998) 109-110.
} 
Hermetism (=Hermes Trismegistus - a theologian and a philosopher), and works astrological, alchemical and magical in their nature, the basis for the so-called technical/popular Hermetism (=Hermes Trismegistus - an astrologer and an

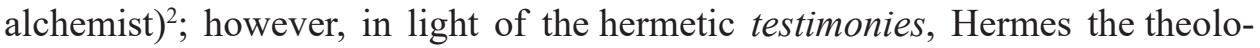
gian was always "following closely" Hermes the master of esotericism. In other words, testimonia and their authors indicate that the above caesura, established between philosophical and practical hermetic texts, seems only to blur the boundaries and serves solely the contemporary task of arranging the hermetic content, with nothing binding their variety together more than their authorship attributed to Trismegistus, who thus becomes a sort of genre indicator. ${ }^{3}$

Trismegistus is a fictional character. However, for many in the bygone times that fiction was an equivalent of history. Nevertheless, by referring to him also as a "legend" or a "myth," one might also appreciate his advantage over any historical figure. Starting from ca. third century BC, he has appeared with varying intensity throughout all the literary-historical periods, assuming various "masks" and becoming a component of the existing cultural reality in the broad sense. ${ }^{4}$

2 See further: A. Sowińska, Hermetica średniowiecza i renesansu. Studium z historii myśli europejskiej (Katowice: Wydawnictwo Uniwersytetu Śląskiego 2018) 10, f.n. 2: "The «higher» Hermetism encompasses religious and philosophical hermetic texts, these are: the Latin tractate Asclepius, seventeen tractates/dialogues comprising a collection known as Corpus Hermeticum, twenty nine hermetic texts and fragments in Stobeus' Anthology, three texts in the sixth codex of the Nag Hammadi Library, Armenian Hermetic Definitions, and the so-called Vienna fragments. The «lower» Hermetism involves texts magical, alchemical, and astrological in their content, the main indication of their identity as hermetic writings is the figure of Hermes Trismegistus occurring within them (also as, for instance: Hermes Mercurius Trismegistus). The Polish terminology regarding the division of Hermetism - into the higher and lower Hermetism - appeared (in all likelihood for the first time) in the texts by Tadeusz Zieliński (cf. T. Zieliński: Hermes Trzykroć-Wielki (Hermes Trismegistos). Studium z cyklu: wspólzawodnicy chrześcijaństwa, Zamość: Pomarański 1921). A division of hermetic literature was also presented (in roughly the same period as that put forth by Zieliński) by Walter Scott (in: W. Scott, Hermetica. The ancient Greek and Latin writings which contain religious or philosophic teachings ascribed to Hermes Trismegistus, vol. 1: Introduction, Texts and Translation (Boston: Shambhala 1985, [1924']), who introduced the terms: 'religious / philosophic' Hermetica (in relation to the higher Hermetism) and 'occult arts and sciences' (for the lower Hermetism). A crucial figure who had major influence on the nomenclature of the divisions of Hermetism was also André-Jean Festugière and his: 'hermétisme savant' (for the higher Hermetism) and 'hermétisme populaire' (i.e. popular, lower Hermetism) — cf. A.-J. Festugière, La Révélation d'Hermes Trismégiste, vol. 1: L'Astrologie et les Sciénces Occultes (Paris: J. Gabalda et Cie 1950)."

3 Cf. M.D. Litwa, Hermetica II. The Excerpts of Stobaeus, Papyrus Fragments, and Ancient Testimonies in an English Translation with Notes and Introduction (Cambridge: Cambridge University Press 2018) 2. Cf. also: G. Fowden, The Egyptian Hermes. A Historical Approach to the Late Pagan Mind (Cambridge: Cambridge University Press 1986) and Ch. Bull, The Tradition of Hermes Trismegistus (Leiden: Brill 2018).

4 See Litwa, Hermetica II, 2. 


\section{a. Testimonia (TH)}

Significant for the contemporary studies, the editions of hermetic texts with translations approached the issue of testimonia in various ways. Walter Scottthe author of a pioneer edition ${ }^{5}$ developed in the 1920s, and hence the first and thorough (at times even hypercritical) one-sacrificed a volume of his work almost in its entirety to hermetic testimonia ( $\rightarrow$ Testimonia, Addenda and Indices), in which under a single title (Testimonia) he published texts that included both fragments (excerpta) of hermetic texts woven into a context, and merely references to the figure of the very "author" of hermetic texts. In volume one, he also cites the modest quotations from the fragments ( $\rightarrow$ Introduction, Texts and Translation, 534-549); however, these were placed in the aforementioned "collective" volume, titled Testimonia.

The leading and nowadays exemplary French edition ${ }^{6}$ of the 1940s and 1950s - authored by André-Jean Festugière and Arthur D. Nock-following Scott's edition used the term fragments (Fr. fragments $\rightarrow$ Fragments Divers) for the texts that are referred to as testimonia by Scott, but with the works containing descriptions of Hermes Trismegistus removed: the French edition includes only the works entailing fragments whether in direct or reported speech. It is worth adding that the term fragmenta (with a qualification Hermetica) pertains in both Scott's and the French edition also to hermetic fragments (i.e. excerpts, abstracts) included in Sobaeus' Anthology $(\rightarrow$ Fragments Extraits de Stobée $(X X I I-X X I X)$ in Festugiere and Nock's version, and Notes on the Latin Asclepius and the Hermetic excerpts of Stobaeus in Scott's edition). Scott uses the term testimonia to any hermetic references found in the works of various authors, regardless whether these are direct extracts from hermetic texts in the form of quotations included in the context of another author's work, or simply an evocation in a work to the hypothetical author of hermetic texts, that is to Hermes Trismegistus.

A strategy similar to that of Festugière and Nock's edition (i.e. of separating fragmenta from testimonia) was adopted by M. David Litwa ${ }^{7}-$ a Research Fellow at the Australian Catholic University, specialised in ancient religions of the Mediterranean, the author of a relatively recent (2018) translation of hermetic

5 W. Scott, Hermetica. The Ancient Greek and Latin Writings which Contain Religious or Philosophic Teachings Ascribed to Hermes Trismegistus. I. Introduction, Texts and Translation. II. Notes on the Corpus Hermeticum. III. Notes on the Latin Asclepius and the Hermetic excerpts of Stobaeus. IV. Testimonia, Addenda and Indices (Boston, MA: Shambhala 1985), 1 ed. (Oxford: Clarendon Press 1924-36) I-IV.

6 A.-J. Festugière - A.D. Nock (eds.), Hermès Trismégiste. Corpus Hermeticum. I. Poimandres, Traités II-XII. II. Corpus Hermeticum. Tome XIII-XVIII. Asclepius. III. Fragments Extraits de Stobée (I-XXII). IV. Fragments Extraits de Stobée (XXII-XXIX); Fragments Divers (Paris: Belles Lettres 2007-2011), 1 ed. (Paris: Belles Lettres 1946-1954) I-IV.

7 Litwa, Hermetica II. 
fragmenta $(F H=$ Fragmenta Hermetica $)$ and testimonia $(T H=$ Testimonia Hermet$i c a)$ to English, in which he included his rendition of: 1) fragments from Sobaeus (SH=Stobean Hermetica), 2) the Oxford fragments (OH=Oxford Hermetica), 3 ) the Vienna fragments (VH=Vienna Hermetica), 4) hermetic fragments from various authors ( $F H=$ Hermetic fragments from various authors $), 5)$ testimonies concerning Hermes Trismegistus (TH=Testimonies concerning Hermes Thrice Great). Litwa's publication constitutes a substantive basis for the first section of this paper, as this anthology of excerpts provides readers with the most current insight into the influence of Hermetism ranging from its origin until the end of the Middle Ages, thus becoming an important introduction and an instrument for further research, incl. the current study. In it I use (as far as possible) the Latin names in the categorisation of testimonia and fragmenta, regarding authors (e.g. Aurelius Augustinus, Zosimus, Psellus, etc.), as well as their works, while in the course of my argument shifting to the universally accepted (and most disseminated) English terminology, additionally furnishing each excerpt cited with a reference to a specific address mentioned before (e.g. $\rightarrow F H 15$ ). The order of hermetic testimonia and fragmenta for a given author I will list according to their works (Litwa frequently changes the order, accepting rather thematic considerations of an excerpt as the basis for their arrangement).

The hermetic testimonia and fragmenta selected and translated by Litwa comprise a range of excerpts from works by various authors, starting from the third century BC until the fifteenth century of the current era. The anthology of testimonia collected by Litwa and each time marked with the abbreviation TH (Testimonia Hermetica) with a subsequent ordinal number (e.g. TH 1) - I base upon his collection, additionally providing footnote information on characters and works - opens with Artapanus (third/second century BC) cited by Eusebius (Eusebius Pamphili; third/fourth century AD) in Praeparatio Evangelica 9.27.4-98 (=TH 1). After him, respectively: Cicero (first century BC) and his De natura deorum $3.56^{9}$ (=TH 2); Manilius (first century AD) - Astronomica $1.25-37^{10}(=T H$ 3 ); Thrasyllus (first century AD) - Pinax (here as a later synopsis; fragm. $)^{11}(=T H$

8 Providing the precise location of a fragment, I follow Litwa each time, citing in the commentary an edition of the text (in a version extended and/or verified by me in terms of its notation) that served as the basis for the translation included in the selected body of texts. Here, the fragment as cited in: Eusèbe de Césarée, La Préparation Évangelique (Introduction, traduction et notes par G. Schroeder É. des Places; texte grec révisé par É. des Places) (SC 369; Paris: Cerf 1991) VIII-IX-X.

9 As cited in: A.S. Pease (ed.), M. Tulli Ciceronis De natura deorum (Cambridge, MA: Harvard University Press 1955-1958) I-II. Cicero's testimonium from De natura deorum was subsequently adopted by Lactantius in his Divinae institutiones 1.6.1-4. See Litwa, Hermetica II, 184 and 261.

10 As cited in: G.P. Goold (ed.), M. Manilii Astronomica (Stuttgart - Leipzig: Teubner 1998).

11 As cited in: H. Tarrant (ed.), Thrasyllan Platonism (Ithaca: Cornell University Press 1993). 
4); Dorotheus Sidonius (first century AD) - Carmen Astrologicum 2.20.1 $1^{12}$ (=TH $5 \mathrm{a}^{13}$ ) and a scholium in Hephaestionis Apotelesmatica 3.6.11 (=TH 5b); Philo Biblius (second century AD) - cited by Eusebius in Praeparatio Evangelica 1.9.24 ${ }^{14}$ (=TH 6a) and 1.10.17-18 (=TH 6b); Athenagoras (second century AD) - Legatio pro Christianis $28.3^{15}$ (=TH 7); Hyppolitus? ${ }^{16}$ (second/third century AD) - Refutatio omnium haeresium 5.14.7 $7^{17}$ (=TH 9; 220-225 AD); Pseudo-Manetho (third century AD) - Apotelesmatica 5.1-10 $0^{18}$ (=TH 10a); Pseudo-Manetho cited by Syncellus (Georgius Syncellus; ninth century AD) in Ecloga Chronographica $72^{19}$ $(=T H 10 \mathrm{~b})^{20}$; Arnobius (third/fourth century AD) -Adversus nationes $2.13^{21}(=T H$ 11); Iamblichus ${ }^{22}$ (third/fourth century AD) - De mysteriis Aegyptiorum 1.1-2, $8.4^{23}$ (=TH 12); Marius Victorinus (third/fourth century AD) - Commenta in Ciceronis Rhetorica $1.39^{24}$ (=TH 13); Emperor Julian (Flavius Claudius Iulianus; fourth century AD) cited by Cyril of Alexandria (Cyrillus Alexandrinus; fourth/ fifth century AD) in Contra Iulianum 5.33.6-925 (=TH 14); Ammianus Marcelli-

12 This and the following fragment, as cited in: D. Pingree (ed.), Dorothei Sidonii Carmen Astrologicum. Interpretationem Arabicam in linguam Anglicam versam una cum Dorothei fragmentis et Graecis et Latinis (Stuttgart: Teubner 1976).

13 The original Greek text was not preserved in its entirety until the modern times. Ca. third century AD, it was translated into Middle Persian (Pahlavi), while ca. the year 800 - into Arabic. See Litwa, Hermetica II, 266, f.n. 1.

14 This and the following fragment, as cited in: Eusèbe de Césarée, La Préparation Évangelique (Introduction, texte grec, traduction et commentaire par J. Sirinelli - É. des Places) (SC 206; Paris: Cerf 1974) I.

15 As cited in: Athenagoras, Legatio pro Christianis (ed. M. Marcovich) (Berlin: de Gruyter 1990).

16 A hypothetical author of the Refutatio... is Hippolytus of Rome - see Hippolytus, Refutatio omnium haeresium (ed. M. Marcovich) (Berlin: de Gruyter 1986). M. David Litwa opts for the text being anonymous - see Litwa, Hermetica II, 271, f.n. 2. See also: E. Castelli, "Saggio introduttivo: L'Elenchos, ovvero una 'biblioteca' contro le eresie," 'Ippolito'. Confutazione di tutte le eresie (ed. A. Magris) (Brescia: Morcelliana 2012) 21-56, and M.D. Litwa, Refutation of All Heresies: Translated with an Introduction and Notes (WGRW 40; Atlanta, GA: SBL 2016).

17 As cited in: Hippolytus, Refutatio omnium haeresium.

18 As cited in: R. Lopilato, The Apotelesamtika of Manetho (Dys. Brown University 1998).

19 As cited in: A.A. Mosshammer (ed.), Georgii Syncelli Ecloga chronographica (Leipzig: Teubner 1984).

20 The passage from the Book of Sothis cited by Syncellus was in all likelihood based on a chronicle compiled by an Alexandrian writer named Pandorus ca. 400 AD. See Litwa, Hermetica II, 275, f.n. 12, and K. van Bladel, The Arabic Hermes: From Pagan Sage to Prophet of Science (New York: Oxford University Press 2009).

21 As cited in: C. Marchesi (ed.), Arnobii Adversus nationes libri VII (CSLP; Torino: Battista 1953).

22 See also: below, the hermetic fragments in Iamblichus.

23 As cited in: Jamblique, Les mystères d'Égypte (ed. É. des Places) (Paris: Belles Lettres 1989).

24 As cited in: C. Marius Victorinus, Commenta in Ciceronis Rhetorica accedit incerti auctoris tractatus de attributis personae et negotio (ed. T. Riesenweber) (BSGRT; Berlin: de Gruyter 2013).

25 As cited in: Kyrill von Alexandrien, Gegen Julian. I. Buch 1-5 (ed. Ch. Riedweg) (Die Griechischen Christlichen Schriftsteller der ersten Jahrhunderte, Neue Folge 20; Berlin: de Gruyter 2016). 
nus (fourth century AD) - Res gestae 21.14.5 $5^{26}$ (=TH 15); Papyri Graecae Magicae (second to fourth century AD) $4.850-887^{27}(=T H$ 16a) and 7.540-55928 $(=T H$ 16b); Filastrius Brixiensis (fourth century AD) - Diversarum hereseon liber $10.2^{29}$ (=TH 17); Aurelius Augustinus ${ }^{30}$ (fourth/fifth century AD) - Contra Faustum 13.1 and $13.15^{31}$ (=TH 19a), De civitate Dei 18.8 and $18.39^{32}$ (=TH 19b); Hermias Alexandrinus (fifth century AD) - In Platonis Phaedrum scholia 2 and $45^{33}$ (=TH 20); Cyrillus Alexandrinus ${ }^{34}$ (fourth/fifth century AD) - Contra Iulianum $1.41^{35}$ (=TH 21); Ioannes Antiochenus (seventh century AD) - Historia chronica $6.2^{36}$ (=TH 22); Isidorus Hispalensis (sixth/seventh century AD) - Etymologiae/Origines 8.9.33 and 8.9.49 ${ }^{37}\left(=T H\right.$ 23); Ioannes Damascenus? ${ }^{38}$ (seventh/ eight century AD) - Passio Artemii 26, 28 and $30^{39}\left(=\right.$ TH 24); Michael Psellus ${ }^{40}$ (eleventh century AD) - Opusculum 43, vv. 40-48 ${ }^{41}$ (=TH 29a), Opusculum 16,

26 As cited in: W. Seyfarth (ed.), Ammiani Marcellini rerum gestarum libri qui supersunt (Leipzig: Teubner 1999) I.

27 As cited in: A. Henrichs - K. Preisendanz (eds.), Papyri Graecae Magicae. Die griechischen Zauberpapyri (München: Saur 2001) I.

28 As cited in: Henrichs - Preisendanz, Papyri Graecae Magicae II.

29 As cited in: F. Heylen (ed.), Filastrii episcopi Brixiensis Diversarum hereseon liber (CCSL 9; Turnhout: Brepols 1957). Is it possible that Filastrius mistook here Hermes for, say, Zalmoxis? In any case, the trip allegedly undertaken by Hermes to the Celts is not attested to by any other source. See Litwa, Hermetica II, 285, f.n. 2.

30 See also: below, the hermetic fragments in Augustine of Hippo.

31 The fragments, as cited in: J. Zycha (ed.), Sancti Aurelii Augustini De utilitate credendi; De duabus animabus; Contra Fortunatum; Contra Adimantum; Contra epistulam fundamenti; Contra Faustum (CSEL 25.6.1; Vienna: Tempsky 1891).

32 The fragments, as cited in: B. Dombart - A. Kalb (eds.), Sancti Aurelii Augustini De civitate Dei (CCSL 47; Turnhout: Brepols 1955).

33 The fragments, as cited in: Hermias Alexandrinus, In Platonis Phaedrum scholia (eds. C.M. Lucarini - C. Moreschini) (Berlin - Boston, MA: de Gruyter 2012).

34 See also: below, the hermetic fragments in Cyril of Alexandria.

35 As cited in: Kyrill von Alexandrien, Gegen Julian I.

36 As cited in: Ioannis Antiocheni Fragmenta ex Historia chronica (Introduzione, edizione critica e traduzione a cura di U. Roberto) (Texte und Untersuchungen zur Geschichte der altchristlichen Literatur 154; Berlin: de Gruyter 2005).

37 The fragments, as cited in: W.M. Lindsay (ed.), Isidori Hispalensis Episcopi Etymologiarum sive Originum libri XX (Oxford: Clarendon Press 1911) I. Writing in the year 860, Hincmar of Rheims is supposed to have cited a testimony of Isidore (8.9.33) in his De divortio Lotharii regis et Theutbergae reginae $\rightarrow$ The Divorce of King Lothar and Queen Theutberga: Hincmar of Rheims's "De Divortio" (trans. R. Stone - Ch. West) (Manchester: Manchester University Press 2016). See also: Litwa, Hermetica II, 294, f.n. 2.

38 On the authorship, see P.B. Kotter (ed.), Die Schriften des Johannes von Damaskos. V. Opera homiletica et hagiographica (PTS 29; Berlin: de Gruyter 1988) 185-187. See also: Litwa, Hermetica II, 295, f.n. 1.

39 The fragments, as cited in: Kotter, Die Schriften des Johannes von Damaskos V.

40 See also: below, the hermetic fragments in Michael Psellus.

41 As cited in: J.M. Duffy - D.J. O’Meara (eds.), Michaelis Pselli Philosophica minora (Leipzig: Teubner 1992) I. 
vv. 34-37 and 44-72 ${ }^{42}\left(=\right.$ TH 29b), Oratio $3^{43}\left(=\right.$ TH 29c), Oratio $1^{44}(=$ TH 29d), scholium in Corpus Hermeticum $1.18^{45}$ (=TH 29e), Opusculum $10.40-51^{46}(=$ TH 29f), Opusculum 18.26-3347 (=TH 29g), Opusculum $106.136-143^{48}$ (=TH 29h), Codex from Bodleian Library (the extract: Arch. Seld. B18, sixteenth century, f. $192 \mathrm{v})^{49}$ (=TH 29i); Albertus Magnus ${ }^{50}$ (twelfth/thirteenth century AD) - Liber mineralium 1.1.4 ${ }^{51}$ (=TH 36a), 2.1.2 (=TH 36b), 2.2.10 (=TH 36c), 3.2.3 (=TH 36d), De somno et vigilia 3.1.5 (=TH 36e), Liber Ethicorum 10.2.3 $3^{53}$ (=TH 36f), De animalibus 22.1.5 (=TH 36g), 25.2 (=TH 36h), Liber de causis et processu universitatis 1.4.35 (=TH 36i); Nicolaus Cusanus ${ }^{56}$ (fifteenth century AD) - De dato patris luminum 2, no. $102^{57}$ (=TH 38a), De beryllo $7^{58}$ (=TH 38b).

Due to the subject matter of the current paper, and considering my ability mainly in Greek and Latin, I refrain from describing in detail Arabic authors, instead acknowledging their existence as regards to their works providing information on Hermes Trismegistus, and hence their influence on dissemination of Hermetism, inter alios - according to Litwa's anthology-Al-Kindī (=TH 25a-b), AbūMa'shar (=TH 26a-b), Ibn an-Nadīm (=TH 27), Al-Mubaššir ibn Fātik (=TH 28). The so-called Arabic Hermetism has been thoroughly researched. ${ }^{59}$ Additionally,

42 As cited in: Duffy - O’Meara, Michaelis Pselli Philosophica minora I.

43 As cited in: G.T. Dennis (ed.), Michaelis Pselli Orationes forenses et acta (Leipzig: Teubner 1994).

44 As cited in: Dennis, Michaelis Pselli Orationes.

45 As cited in: Duffy - O’Meara, Michaelis Pselli Philosophica minora II.

46 As cited in: P. Gautier (ed.), Michaelis Pselli Theologica (Munich - Leipzig: Teubner 2002) I.

47 As cited in: J.M. Duffy - L.G. Westerink (eds.), Michaelis Pselli Theologica (Munich - Leipzig: Teubner 2002) II.

48 As cited in: Gautier, Michaelis Pselli Theologica I.

49 As cited in: Litwa, Hermetica II, 313; see also: J. Bidez - F. Cumont, Mages hellénisés: Zoroastre, Ostanès et Hystaspe d'après la tradition grecque (Paris: Belles Lettres 1938) II.

50 See also: below, the hermetic fragments in Albertus Magnus.

51 This fragment and the following ones, as cited in: Albertus Magnus, Mineralium libri quinque (ed. A. Borgnet) (B. Alberti Magni Opera Omnia 5; Paris: Vivès 1890).

52 As cited in: Albertus Magnus, De somno et vigilia (ed. A. Borgnet) (B. Alberti Magni Opera Omnia 9; Paris: Vivès 1890).

53 As cited in: Albertus Magnus, Ethicorum libri X (ed. A. Borgnet) (B. Alberti Magni Opera Omnia 7; Paris: Vivès 1891).

54 This and the following fragment, as cited in: Albertus Magnus, De animalibus libri XXVI, nach der Cölner Urschrift (ed. H. Stadler) (Münster: Aschendorff 1916-1921) II.

55 As cited in: Albertus Magnus, Liber de causis et processu universitatis (ed. A. Borgnet) (B. Alberti Magni Opera Omnia 10; Paris: Vivès 1891).

56 See also: below, the hermetic fragments in Nicholas of Cusa.

57 As cited in: P. Wilpert (ed.), Nicolai de Cusa Opera omnia. IV. Opuscula. 1. De Deo abscondito, De quaerendo Deum, De filiatione Dei, De dato patris luminum, Coniectura de ultimis diebus, De genesi (Hamburg: Meiner 1959).

58 H.G. Senger - K. Bormann (eds.), Nicolai de Cusa Opera omnia. IX.1. De beryllo (Hamburg: Meiner 1988).

59 See Litwa, Hermetica II, 297-307. I refer the readers interested in the notion of Arabic Hermetism to the relatively abundant literature on the subject (see Litwa, Hermetica II, 297-307, especially bib- 
we ought to note the fact that some texts classified in the genre of Hermetica in their provenance or, say, translation reach the Arabic literary sphere.

Litwa also treated as testimonia excerpts from texts of varied attribution, typically categorised as Hermetica or pseudo-Hermetica, incl. works created on the basis of the cited words allegedly spoken by Hermes: De virtutibus herbarum (=TH 8; second century $\mathrm{AD}^{60}$ ); prologue to the work Cyranides (=TH 18; fourth/ fifth century $\left.\mathrm{AD}^{61}\right)$; Tabula Smaragdina (=TH 30a-b; translatio Latina: twelfth century AD, ${ }^{62}$ textus Arabicus ${ }^{63} /$ Graecus: 600-750 AD $\left.{ }^{64}\right)$; Liber de compositione

liographic descriptions in footnotes), with particular attention worth paying to: Bladel, The Arabic Hermes and s.v. "Hermetic Literature III: Arab," DGWE. See also, among others: K. van Bladel, "Sources of the Legend of Hermes in Arabic," Hermetism from Late Antiquity to Humanism / La tradizione ermetica dal mondo tardo-antico all'Umanesimo. Atti del Convegno internazionale di studi, Napoli, 20-24 novembre 2001 (eds. P. Lucentini - I. Parri - V. Perrone Compagni) (Turnhout: Brepols 2003) 285-293; M. Pappacena, "La figura di Ermete Trismegisto nella tradizione Araba," Hermetism from Late Antiquity to Humanism / La tradizione ermetica dal mondo tardo-antico all'Umanesimo. Atti del Convegno internazionale di studi, Napoli, 20-24 novembre 2001 (eds. P. Lucentini - I. Parri - V. Perrone Compagni) (Turnhout: Brepols 2003) 263-283; A.E. Affifi, "The Influence of Hermetic Literature on Moslem Thought," BSOAS 13/4 (1951) 840-855; M. Plessner, "Hermes Trismegistus and Arab Science," SI 2 (1954) 45-59; Ch. Burnett, "The Legend of the Three Hermes and Abū-Ma'shar's Kitab al-Ulüf in the Latin Middle Ages," JWCI 39 (1976) 231-234; A. von Lieven, "Thot selbdritt. Mögliche ägyptische Ursprünge der arabisch-lateinischen Tradition dreier Hermesgestalten," WO 37 (2007) 69-77; F.E. Peters, "Hermes and Harran. The Roots of Arabic-Islamic Occultism," Intellectual Studies on Islam (eds. M.M. Mazzaou - V.B. Moreen) (Salt Lake City, UT: University of Utah 1990) 185-215; B. Dodge, The Fihrist of al-Nadim. A Tenth-century Survey of Muslim Culture (New York: Columbia University Press 1970) I-II; T.M. Green, The City of the Moon God. Religious Traditions of Harran (Leiden: Brill 1992); D. Pingree, "The Sābians of Harrān and the Classical Tradition," IJCT 8 (2002) 8-35.

60 On the dating, see I.S. Moyer, "A Revised Astronomical Dating of Thessalus's De virtutibus herbarum," The Frontiers of Ancient Science: Essays in Honor of Heinrich von Staden (ed. B. Holmes) (Berlin: de Gruyter 2015) 437-449. Two recensiones of the text are extant: the longer one, attributed to Thessalus (probably Thessalus of Tralles, a physician, dec. in 79 AD), and the shorter one, attributed to Hermes Trismegistus himself. See Litwa, Hermetica II, 269, and H.-V. Friedrich (ed.), Thessalos von Tralles griechisch und lateinisch (Meisenheim am Glan: Hain 1968) (here also an edition of the text).

61 Litwa's translation, according to D. Kaimakis (ed.), Die Kyraniden (Meisenheim am Glan: Hain 1976). The dating of Greek version of the text of Cyranides/Kyranides on the basis of the article by K. Alpers, "Untersuchungen zum griechischen Physiologus und den Kyraniden," VB 6 (1984) 13-87. A Latin translation of another Greek version of that work is also extant: L. Delatte, Textes latins et vieux français relatifs aux Cyranides (Paris: Droz 1942). See Litwa, Hermetica II, 286, f.n. 1.

62 See TH 30a (translatio Latina [the period of: 1134-1145]: Plato Tiburtinus) $\rightarrow$ D. Waley Singer R. Steele, "The Emerald Table," PRSM 21 (1927) 485-501. TH 30b (translatio Latina [the period of: 1145-1151]: Hugo Sanctelliensis) $\rightarrow$ F. Hudry, "Le De secretis naturae du pseudo-Apollonius de Tyane: Traduction latine par Hugues de Santalla du Kitâb sirr al-halîqa de Balînnûs," Chrysopoeia 6 (1997-1999) 1-154. The TH 30a version is said to have been used by Albert the Great and Arnold de Villanova. See Litwa, Hermetica II, 314, f.n.1.

63 See U. Weisser, Das “Buch über das Geheimnis der Schöpfung” von Pseudo-Apollonios von Tyana (Berlin: de Gruyter 1980).

64 See J. Ruska, Tabula Smaragdina. Ein Beitrag zur Geschichte der hermetischen Literatur (Heidelberg: Winter 1926) 166. 
alchemiae ( $\rightarrow$ praefatio Castrensis) $\left(=\right.$ TH 31a; praefatio Castrensis: $\left.1144 \mathrm{r}^{65}\right)$; De sex rerum principiis ( $\rightarrow$ praefatio) $(=$ TH 31b;1147-1180 AD); Liber viginti quattuor philosophorum $\left(=\right.$ TH 32; twelfth century $\left.\mathrm{AD}^{66}\right)$; Liber de Alcidi de immortalitate animae $\left(=T H 33\right.$; twelfth century $\left.\mathrm{AD}^{67}\right)$; De quindecim stellis, quindecim lapidibus, quindecim herbis et quindecim imaginibus (=TH 34; twelfththirteenth century $\left.\mathrm{AD}^{68}\right)$; Liber de stellis beibeniis $(=T H 35$; thirteenth century $\left.\mathrm{AD}^{69}\right)$; Picatrix $\left(=\right.$ TH 37a-e; translatio Latina: thirteenth century $\left.\mathrm{AD}^{70}\right)$ - these excerpts constitute a rather distinct branch of sources, as they comprise a part of texts that could be classified in the collection of hermetic (or pseudo-hermetic) works; nevertheless, they indicate a constant progress of hermetic literature over time.

65 The issue of the dating of praefatio Castrensis remains disputable. It is assumed to have been created in 1144 (see R. Halleux, "The Reception of Arabic Alchemy in the West," Encyclopedia of the History of Arabic Science [ed. R. Rashed] [London: Routledge 1996] III 886-902), but some scholars opt for the turn of the thirteenth and the fourteenth century (see J. Ruska, "Zwei Bücher de Compositione Alchemiae und ihre Vorreden," AGMNT 11 [1928] 28-37). Additionally, the twelfth century dating is adopted by L. Stavenhagen, "The Original Text of the Latin Morienus," Ambix 17 (1970) 1-12. See Litwa, Hermetica II, 317 (especially f.n. 1).

66 More on the attribution of the text (some medieval manuscripts attribute the authorship to Hermes Trismegistus, other leave the text anonymous) and on its dating (the assumptions expressed in the text may go as far back as to the third century AD, thus originating in the Egyptian Alexandria, at the time a melting pot of cultures, or in the fourth century with Gaius Marius Victorinus and his oeuvre), see Hermes Trismegistus, Liber viginti quattuor philosophorum (ed. F. Hudry) (Turnhout: Brepols 1997); idem, Le livre des XXIV philosophes. Résurgence d'un texte du IVe siècle (ed. F. Hudry) (Paris: Vrin 2009); see also: Litwa, Hermetica II, 320 (especially f.n. 1).

67 See P. Lucentini, Liber Alcidi de immortalitate animae. Studio e edizione critica (Naples: Istituto Universitario Orientale 1984).

68 The alleged Greek original of the text was lost; in the eight century, an Arabic astronomer was said to disseminate the version of the text, which in the twelfth or thirteenth century came to be translated to Latin. See Litwa, Hermetica II, 324, f.n. 1, and P. Lucentini - V. Perrone Compagni, I testi e and codici di Ermete nel Medioevo (Firenze: Polistampa 2001) 47-48.

69 The basis of the text goes back to the third century BC - whereas the oldest extant version of the work dates back to $379 \mathrm{AD}$. The Greek original was translated into Middle Persian (Pahlavi), Arabic (ninth century AD) and into Latin (ca. 1218 in Toledo by Salio of Padua). See Litwa, Hermetica II, 326, and [Hermes Trismegistus] "Liber de stellis beibeniis. Textus Arabicus et translatio," Latina Hermetis Trismegisti astrologica et divinatoria (ed. G. Bos et al.) (Turnhout: Brepols 2001) 9-99; P. Kunitzsch, "Origin and History of Liber de stellis beibeniis," Hermetism from Late Antiquity to Humanism $/$ La tradizione ermetica dal mondo tardo-antico all'Umanesimo. Atti del Convegno internazionale di studi, Napoli, 20-24 novembre 2001 (eds. P. Lucentini - I. Parri - V. Perrone Compagni) (Turnhout: Brepols 2003) 449-460.

70 The Arabic original dates back to the eleventh century AD, the author of the work is unknown, though it is often attributed to the mathematician and astronomer Maslama ibn Ahmad al-Majriti (dec. between 1005 and 1008); the Spanish paraphrase/adaptation of the text was created between 1256 and 1258, the Latin translation is said to have been created shortly afterwards. See Litwa, Hermetica II, 333, f.n. 1, and, among others: D. Pingree, Picatrix: The Latin Version of the Ghayat Al-Hakim (London: Warburg Institute 1986); idem, "Some of the Sources of the Ghāyat al-Hakìm," JWCI 43 (1980) 1-15; Picatrix: Un traité de magie médiéval (transl., introduction and comments by B. Bakhouche et al.) (Turnhout: Brepols 2003). 
Majority of the collected testimonia present Trismegistus as a champion of natural sciences, specifically: astronomy/astrology, e.g. in Manilius $(\rightarrow T H 3)$, Thrasyllus ( $\rightarrow T H 4)$, Dorotheus of Sidon ( $\rightarrow T H$ 5a and b), Pseudo-Manetho $(\rightarrow T H 10 \mathrm{a}$ and b), Iamblichus ( $\rightarrow T H 12)$, Cyril of Alexandria ( $\rightarrow T H 21)$, John of Antioch ( $\rightarrow T H 22)$, Michael Psellus ( $\rightarrow T H 29 \mathrm{~b})$, Albert the Great $(\rightarrow T H 36 \mathrm{~b})$; medicine, as in John of Damascus (?) ( $\rightarrow$ TH 24); chronology - in Marius Victorinus ( $\rightarrow T H$ 13); alchemy, as in Michael Psellus ( $\rightarrow T H$ 29i [?]) and Albert the Great ( $\rightarrow$ TH 36d and h;36h - here a mention in a lecture on animals); mineralogy and petrology, e.g. in Albert the Great ( $\rightarrow$ TH 36a-d). They concurrently provide an image of Trismegistus as: a philosopher and a theologian, as in Iamblichus ( $\rightarrow T H$ 12), Ammianus Marcellinus ( $\rightarrow T H 15)$, Augustine $(\rightarrow T H$ 19a and b), Hermias ( $\rightarrow$ TH 20), Michael Psellus ( $\rightarrow$ TH 29a-i- though in $T H 29 \mathrm{e}$, Psellus attempts to undermine the authority of Trismegistus, referring to him as a "mage"), Nicholas of Cusa ( $\rightarrow$ TH 38a and b); a wisemen versed in many arts, according to: Cyril of Alexandria ( $\rightarrow T H 21)$ - describing in detail the numerous fields in which Trismegistus played the leading role and those he "presented" to society - John of Antioch ( $\rightarrow T H 22$ ), Isidore of Seville ( $\rightarrow T H 23$ ), John of Damascus (?) ( $\rightarrow$ TH 24), and Albert the Great ( $\rightarrow$ TH 36a-i), in whose oeuvre Trismegistus appears as the authority in natural sciences, as well as a theologian and a philosopher - rolled into one.

\section{b. Fragmenta $(\mathrm{FH})$}

Outlining the range of influence of hermetic texts, and thus following the development of their tradition, one has to pay particular attention to the hermetic excerpta drawn from the texts attributed to the legendary figure of Trismegistus. These tend to be the fragments or paraphrases of fragments of the leading hermetic works, that is the tractate Asclepius, and a collection of works (usually taking the form of a dialogue), known as the Corpus Hermeticum. In not very numerous cases, the authors point to a specific hermetic work (by identifying its title) that they had drawn from, and which is no longer available. Thus, hermetic literature was used subsequently (according to Litwa's anthology) by: Tertullianus (second/ third century AD; Tertullianus is supposed to have been the first among Latin authors to mention Hermes Trismegistus and in a way establish the Latin recaption of the hermetic tradition $\left.{ }^{71}\right)$ - Contra Valentinianos $15.1^{72}$ (=FH 1a), De anima 2.1, $3^{73}$ (=FH 1b), 28.1 (=FH 1c), 33.2 (=FH 1d); Pseudo(?)-Cyprianus (third century

71 Litwa, Hermetica II, 177.

72 As cited in: J.-C. Fredouille (ed.), Tertullien. Contre les Valentiniens (SC 280; Paris: Cerf 1980) I.

73 All locations from De anima according to: J.H. Waszink (ed.), Quinti Septimi Florentis Tertulliani "De anima" (Leiden: Brill 2010). 
AD) - Quod idola dii non sint $6^{74}(=F H 2)$; Lactantius (third/fourth century AD) Divinae institutiones 1.6.1-4 (=FH 3a), 1.7.2 (=FH 4a), 1.11.61 (=FH 5a), 2.8.48 (=FH 6), 2.10.14 (=FH 8a), 2.14.6 (=FH 9), 2.15.6 (=FH 10), 4.7.3 (=FH 11a), 4.8.4-5 (=FH 13), 4.9.3 (=FH 12b), 4.13.2 (=FH 4b), 7.4.3 (=FH 8b), 7.9.11 (=FH 14), 7.13.3 (=FH 15), Epitome Divinarum institutionum 4.4. (=FH 4c), 4.4-5 (=FH 3b), 14.3 (=FH 5b), 37.8 (=FH 11b) ${ }^{75}$; Iamblichus - De mysteriis Aegyptiorum 8.6 ( $=F H 16), 10.7$ ( $=F H 17)$, and $F H$ in other authors drawing from Iamblichus: Proclus: In Timaeum 117d (=FH 18) (cf. De mysteriis Aegyptiorum 8.3) ${ }^{76}$; Zosimus Panopolites (third/fourth century AD) - On the Letter Omega $4^{77}$ (=FH 19), 5 (=FH 20), 7 (=FH 21a), and the quotation from Zosimos in: Georgius Syncellus - Ecloga chronographica $24^{78}$ (=FH 21b); Ephraem Syrus (fourth century AD) - Prose Refutations 2.208-210 $0^{79}(=F H$ 22); Cyrillus Alexandrinus Contra Iulianum 1.48.14-1.49.7 (=FH23), 1.49.8-17 (=FH24), 1.43.14-29 (=FH 25), 1.44.1-11 (=FH 26), 1.46.9-12 (=FH 27), 1.46.13-18 (=FH 28), 1.46.19-28 (=FH 29), 1.46.29-34 (=FH 30), 2.29.19-2.30.8 (=FH 31), 2.30.9-11 (=FH 32a), 2.30.12-18 (=FH 32b), 2.29.19-25 (=FH 33a), 2.31.10-16 (=FH34), 8.31.17-24 $(=F H 35)^{80}$; Marcellus Ancyranus (third/fourth century AD) - De sancta ecclesia

74 As cited in: P. Campbell (ed.), The Complete Works of Saint Cyprian of Carthage (Merchantville, NJ: Evolution 2013).

75 All locations from Divinae institutiones and Epitome, as cited in: L. Caelius Firmianus Lactantius, Divinarum institutionum libri septem (eds. E. Heck - A. Wlosok) (BSGRT; Berlin: de Gruyter 2005-2007) I-II; Lactance, Institutions divers livre (ed. P. Monat) (SC 377; Paris: Cerf 1992) IV; E. Heck - A. Wlosok (eds.), L. Coeli Firmiani Lactanti Epitome Divinarum institutionum (BSGRT; Stuttgart - Lepizig: Teubner 1994); Lactance, Épitomé des Institutions Divine (ed., trans. M. Perrin) (SC 335; Paris: Cerf 1992). See Litwa, Hermetica II, 184-192.

76 See Litwa, Hermetica II, 194-195, and the editions: Jamblique, Les mystères d'Égypte; Iamblichus, De mysteriis (eds. E.C. Clark - J.M. Dillon - J.P. Hershbell) (WGRW 4; Atlanta, GA: SBL 2003) and J.M. Dillon (ed.), Iamblichi Chalcidensis In Platonis Dialogos Commentariorum Fragmenta (Philosophia Antiqua 23; Leiden: Brill 1973).

77 All locations from On the Letter Omega, as cited in: Zosime de Panopolis, Les alchimistes grecs. IV/1. Mémoires authentiques (text and trans. M. Mertens) (Paris: Belles Lettres 1995). See Litwa, Hermetica II, 197-201.

78 As cited in: Mosshammer, Georgii Syncelli Ecloga chronographica.

79 As cited in: C.W. Mitchell, S. Ephraim's Prose Refutations of Mani, Marcion, and Bardaisan (London: Williams \& Norgate 1921) II.

80 See Litwa, Hermetica II, 206-214, see also: FH in other authors drawn from the oeuvre by Cyril (most of all from his Contra Iulianum): Ioannes Malalas: Chronographia 2.4 (cf. Contra Iulianum 1.49.10-12, 1.48.15-23, 1.46.9-12, 1.46.2-4; additionally, the fragment from Malalas' text was subsequently adapted by John of Antioch [Ioannes Antiochenus] and George Cedrenus [Georgius Cedrenus]), 13.36; [anonymous]: Theosophia 2.32 (cf. Contra Iulianum 1.48.15-19), 2.33 (cf. Contra Iulianum 1.48.20-23), 2.34 (cf. Contra Iulianum 1.46.30-33), 2.35 (cf. Contra Iulianum 1.46.9-12), 2.37, 2.42 (cf. Contra Iulianum 1.49.14-17), 1.40=Theosophia 21; [a Syriac collection of prophecies of the pagan philosophers]: 4 (cf. Contra Iulianum 1.49.10-12, 1.48.15-18, 1.46.9-11, 1.46.2-4), 14 (cf. Contra Iulianum 1.46.11-12), 19 (cf. Contra Iulianum 1.49.1-7); Iacobus Edessenus: Hexaemeron fragm. (cf. Contra Iulianum 2.30.12-18, 2.29.19-25); Suda s.v. Hermês ho Trismégistos (cf. Contra Iulianum 1.48.16-23, 1.46.9-12, 1.46.2-4); Bar Hebraeus: Liber candelabri sanctuarii III fragm. 
7-16 $6^{81}$ (=FH 36); Ioannes Lydus (fifth/sixth century AD) - De mensibus $4.7^{82}$ (=FH 37b), $4.32+4.149$ (=FH 37c), 4.53 (=FH 37d), 4.64 (=FH 37a); Gregorius Nazianzenus (fourth century AD) - Oratio $28.4^{83}$ (=FH 38); Didymus Alexandrinus (fourth century AD) -Expositio in Ecclesiastes 5-6, 167.15-2384 (=FH 39a), Expositio in Psalmos 22-26.10, 88.8-18 ${ }^{85}$ (=FH 39b); Caius Iulius Romanus (third/fourth century AD) as cited in: Flavius Sosipater Charisius (fourth century AD) - Ars grammatica 2.16 $6^{86}(=F H 40)$; Aurelius Augustinus - De civitate Dei 8.23-26 (=FH 41 $)^{87}$; Quodvultdeus (fifth century AD) - Adversus quinque haereses 3.4-21 $1^{88}$ (=FH 42); Michael Psellos - Opusculum 19.148-150 (=FH 43) ${ }^{89}$; Albertus Magnus - Liber mineralium 3.1.6 $6^{90}$ (=FH 44a), 4.7 (=FH 44b), De intellectu et intelligibili 2.1.6 $6^{91}$ (=FH 44c), 2.1.9 (=FH 44d); Nicolaus Cusanus - De docta ignorantia $1.24^{92}$ (=FH 45a), 1.25 (=FH 45b), 2.8 (=FH 45c).

(cf. Contra Iulianum 1.48.14-1.49.7, 1.46.9-12) - see Litwa, Hermetica II, 215-223 and the editions and translations: Kyrill von Alexandrien, Gegen Julian I; idem, Gegen Julian. II. Buch 6-10 und Fragmente (eds. W. Kinzig - Th. Brüggemann) (GCS Neue Folge 21; Berlin: de Gruyter 2017); I. Thurn (ed.), Ioannis Malalae Chronographia (CFHB 35; Berlin: de Gruyter 2000); P.F. Beatrice, Anonymi Monophysitae theosophia. An Attempt at Reconstruction (Leiden: Brill 2001); S. Brock, "A Syriac Collection of Prophecies of the Pagan Philosophers," OLP 14 (1983) 203-246; A. Vaschalde (ed.), Iacobi Edesseni Hexaemeron seu in opus creationis libri septem (CSCO 97; Scriptores Syri 48; Leuven: Durbecq 1953) (translatio Latina) and I.-B. Chabot (ed.), Iacobi Edesseni Hexaemeron seu in opus creationis libri septem (CSCO; Scriptores Syri 56; Paris: Typographeo Reipublicae 1928) (textus Syrus); A. Adler (ed.), Suidae Lexicon (Stuttgart: Teubner 1967) II; S. Brock, "Some Syriac Excerpts from Greek Collection of Pagan Prophecies," VCh 38 (1984) 77-90.

81 As cited in: A.H.B. Logan, "Marcellus of Ancyra (Pseudo-Anthimus), 'On the Holy Church': Text, Translation, and Commentary," JTS 51 (2000) 81-112.

82 All locations from De mensibus, as cited in: R. Wuensch (ed.), Ioannis Lydi liber de mensibus (Stuttgart: Teubner 1967).

83 As cited in: Gregoire de Nazianze, Discours 27-31 (Discours theologiques) (ed. P. Gally) (SC 250; Paris: Cerf 1978).

84 As cited in: Didymos der Blinde, Kommentar zum Ecclesiastes (Tura Papyrus). III. Kommentar zu Ecclesiastes Kap. 5 und 6 (eds. L. Koenen - J. Kramer) (Bonn: Habelt 1970).

85 As cited in: Didymos der Blinde, Psalmenkommentar (Tura Papyrus). II. Kommentar zu Psalm 22-26, 10 (ed. M. Gronewald) (Bonn: Habelt 1968).

86 As cited in: Ch. Barwick -F. Kūhnert (ed.), Flavii Sosipatri Charisii Artis grammaticae libri V(Stuttgart: Teubner 1997).

87 See Litwa, Hermetica II, 238-244, and the edition: Dombart - Kalb, Sancti Aurelii Augustini De civitate Dei.

88 As cited in: R. Braun (ed.), Opera Quodvultdeo Carthaginiensi episcopo tributa (CCSL 60; Turnhout: Brepols 1976).

89 See Litwa, Hermetica II, 249, and the edition: Duffy - L.G. Westerink, Michaelis Pselli Theologica II.

90 All locations from Liber mineralium, as cited in: Albertus Magnus, Mineralium libri quinque (ed. A. Borgnet) (B. Alberti Magni Opera Omnia 5; Paris: Vivès 1890). See Litwa, Hermetica II, 251-252.

91 All locations from De intellectu et intelligibili, as cited in: Albertus Magnus, De intellectu et intelligibili (ed. A. Borgnet) (B. Alberti Magni Opera Omnia 9; Paris: Vivès 1890). See Litwa, Hermetica II, 252.

92 All locations from De docta ignorantia, as cited in: E. Hoffmann - R. Klibansky (eds.), Nicolai de Cusa Opera omnia. I. De docta ignorantia (Leipzig: Meiner 1932). See Litwa, Hermetica II, 255-256. 
The hermetic fragments $(F H)$ used by the above listed authors are centred on several issues. The hermetic excepta in Tertullian concern the source and essence of matter $(\rightarrow F H$ 1a) and of the soul $(\rightarrow F H$ 1b-d). Pseudo-Cyprian highlights Trismegistus' theory of a one, unknowable God $\left(\rightarrow F H 2^{93}\right)$. Lactantius in numerous hermetic fragments he cited is particularly interested in hermetic theology $\left(\rightarrow F H 3 a^{94}-\mathrm{b}, 4 \mathrm{a}-\mathrm{c}, 5 \mathrm{a}^{95}-\mathrm{b}, 6,7,{ }^{96} 9,{ }^{97} 10,{ }^{98} 11 \mathrm{a}-\mathrm{b}, 12 \mathrm{a}-\mathrm{b}, 13^{99}\right)$ and hermetic anthropology $\left(\rightarrow F H 8 \mathrm{a}^{100}-\mathrm{b}, 14,15^{101}\right.$; more on the subject, see section 2 of this paper: Homo duplicis naturae. Hermetic Anthropology: FH 15). In the hermetic passages cited by Iamblichus, we recognise theses pertaining to the soul $\left(\rightarrow F H 16^{102}\right)$, good (Good), and God $\left(\rightarrow F H 17^{103}\right)$, as well as matter $(\rightarrow F H$ 18). Zosimos, on the basis of excerpts from hermetic works, speaks of issues pertaining to fate/destiny $\left(\rightarrow F H 19,{ }^{104} 20^{105}\right)$ and the results of the interactions between the fallen angels and women $(\rightarrow F H$ 21b). Ephrem the Syrian, in turn, compares the Manichaean doctrines with those attributed, among others, to Hermes Trismegistus, regarding Good, soul, and the resurrection $\left(\rightarrow F H 22^{106}\right)$ - the problem of the "mixing bowl" emerges here, so does a motif (referred to as krater) in a hermetic work from the Corpus Hermeticum (see $\mathrm{CH}$ 4). Also Cyril of Alexandria would profusely draw from hermetic texts - in his Contra Iulianum the hermetic excerpts were adapted to the theological discourse $\left(\rightarrow\right.$ FH 23, $\left.{ }^{107} 24,25,{ }^{108} 26,{ }^{109} 27,{ }^{110} 28,{ }^{111} 29,{ }^{112} 30\right)$ and that on the creation of the world $\left(\rightarrow F H\right.$ 31, 32a-b, $\left.{ }^{113} 33 \mathrm{a},{ }^{114} 34,35^{115}\right)$. Among the hermetic excerpts used by Marcellus of Ancyra, there are theological assumptions and hypothe-

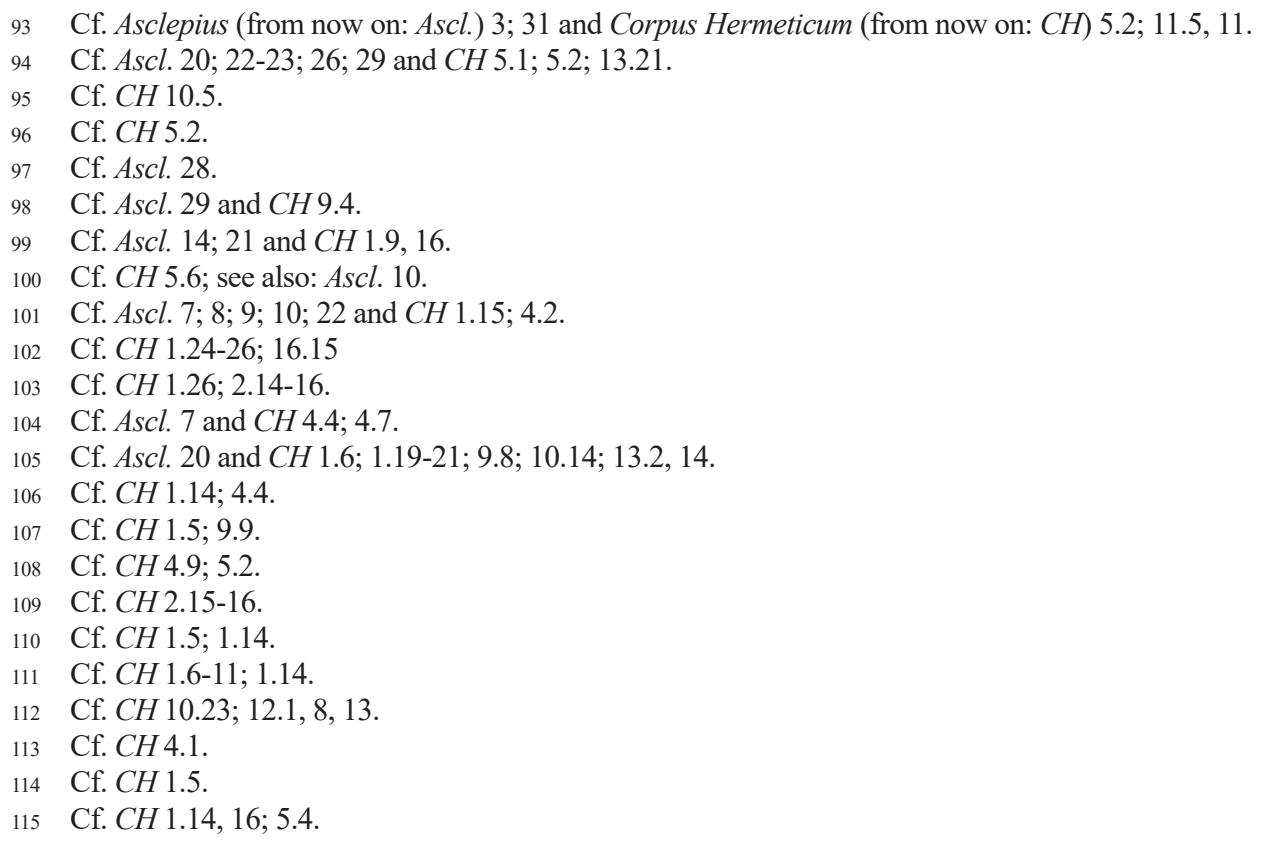


ses regarding Trismegistus' associations with heresies $\left(\rightarrow F H 36^{116}\right)$; in John the Lydian (John Lydus) the hermetic excerpts are mentioned in the context of androgyny $\left(\rightarrow F H 37 \mathrm{a}^{117}\right)$, destiny and necessity $\left(\rightarrow F H 37 \mathrm{~b}^{118}\right)$, as well as angelology $\left(\rightarrow F H 37 \mathrm{c}^{119}\right)$, and theology $(\rightarrow F H 37 \mathrm{~d})$, a subject matter addressed also by Gregory of Nazianzus, with a corroboration from i.a. a hermetic excerpt $(\rightarrow F H 38$ ). Didymus the Blind in his commentaries benefits from hermetic fragments on destiny $\left(\rightarrow F H 39 \mathrm{a}-\mathrm{b}^{120}\right)$, and the grammarian Gaius Iulius Romanus, cited by - another grammarian-Charisius, in a lexical context and that of the origin of mankind $\left(\rightarrow F H 40^{121}\right.$ ). Augustine attacks idolatry, broadly commenting on the hermetic works related thereto $\left(\rightarrow F H 41^{122}\right)$. A similarly hermetic source as that used by Augustine (however, from its different section) proves valuable for the bishop of Carthage - Quodvultdeus - in his analyses of theological issues (God, Son, God's will) in relation to the five heresies. However, contrary to Augustine, Quodvultdeus treats the writing of Trismegistus as his crown apologetic argument; hence, Trismegistus appears here as a witness of veritas christiana $\left(\rightarrow F H 42^{123}\right)$. Michael Psellus, in turn, cites a hermetic phrase in the context of the principles of human cohabitation $(\rightarrow F H 43)$. Albert the Great, owing to the excerpts that he used, presents the figure of Trismegistus the alchemist and the mineralogist ( $\rightarrow F H 44 \mathrm{a}-\mathrm{b})$, and at the same time as a wiseman versed both in philosophy and theology $\left(\rightarrow F H 44 \mathrm{c}^{124}-\mathrm{e}\right)$. The latter two specialities distinguishing Trismegistus are eventually apparent in the hermetic excerpts in Nicholas of Cusa $\left(\rightarrow\right.$ FH 45a, $\left.{ }^{125} \mathrm{~b}^{126} \mathrm{c}^{127}\right)$.

\section{Homo duplicis naturae. Hermetic Anthropology: FH 15}

[...] a human being is a great wonder, a living thing to be worshipped and honored: for he changes his nature into a god's, as if he were a god $[\ldots]$; he despises the part of him that is human

\footnotetext{
116 Cf. Ascl. 8 and $C H$ 8.2.

117 Cf. Ascl. 20 and $\mathrm{CH} 1.9$.

118 Cf. Ascl. 39.

119 Cf. Ascl. 28; 33 and $C H 1.23$.

120 Cf. $C H 1.15 ; 13.11$.

121 Cf. $C H 7.2$.

122 Cf. Ascl. 23; 24; 37.

123 Cf. Ascl. 8, cf. also $C H$ 9.8; 10.14; 13.1-2.

124 Cf. $\mathrm{CH} 12.4$.

125 Cf. Ascl. 20 and $C H$ 5.10.

126 Cf. Ascl. 21.

127 Cf. Ascl. 14-15.
} 
nature, having put his trust in the divinity of his other part. How much happier is the blend of human nature! Conjoined to the gods by a kindred divinity, he despises inwardly that part of him in which he is earthly. ${ }^{128}$

The glory and tragedy of the human condition is that, of all living beings, man alone has a twofold nature, earthly and mortal on the one hand and divine and immortal on the other. ${ }^{129}$

The testimonia and fragmenta indicated in section one of this article constitute a cross section through notes, interpretations, and recurrent theses regarding Hermes Trismegistus, to be found in the texts by authors from the times before our era all the way to the Middle Ages. Meanwhile, modernity leads the way in subsequent editions of hermetic texts (especially: Asclepius and Corpus Hermeticum) both in the original, and in vernacular, as well as Latin renditions, as in the case of Corpus Hermeticum (Asclepius was originally compiled in ancient Greek, but since the early Christian writers, authors have tended to use the Latin paraphrase of the text). The profuse tradition of the above testimonia and fragmenta enables one to trace the way of hermetic thought - both chronologically and geographically - thus indicating the wide range of influence of the texts attributed to Hermes Trismegistus and patterned after him.

The hermetic testimonia and fragmenta found in various works and situated in specific contexts are far from homogenous. That means that the evaluation of Trismegistus based on those texts - in our case particularly by Christian authors - is not always either clear-cut positive or downright negative. Lactantius, besides say Didymus, known as the Blind, Cyril of Alexandria and Quodvultdeus - and contrary to, for instance, Marcellus of Ancyra and Augustine (though the latter does take into consideration a positive aspect of Trismegistos), who nota bene when writing his (no longer extant) On Beauty and Proportion and the Confessions, might have been inspired in several passages by hermetic works $(\rightarrow \mathrm{CH} 5 \text { i } \mathrm{CH} 7)^{130}$ - represents an attitude "favourable" for the image of Hermes, considering to be a prophet of Christian dogmata, and the hermetic thought to

128 Ascl. 6. English translation in: B. Copenhaver, Hermetica. The Greek Corpus Hermeticum and the Latin Asclepius in a new English translation, with notes and introduction (Cambridge: Cambridge University Press 1992) 69.

129 Cf. R. van den Broek, "Hermetism," DGWE, 562.

130 Conf. 1.7 and 5.14: mortem vitalem $\approx C H 7.2$ : tòn dzônta thánaton and the title: De pulchro et apto $\approx$ pánta perikallê kaì pánta memetrēména. See Litwa, Hermetica II, 236 (especially. f.n. 1), and J. van Oort, "Augustine and Hermes Trismegistus: An Inquiry into the Spirituality of Augustine's «Hidden Years»," JECH 6 (2016) 55-76. 
be compatible with the idea of Christianity. ${ }^{131}$ Such a positive depiction of Trismegistus pervaded the medieval tradition (as well as reception) of Hermetism, and may serve as an explanation of the fact that why Byzantine scholars amassed texts we know today as Corpus Hermeticum, ${ }^{132}$ that Lactantius so profusely drew upon. ${ }^{133}$ Moreover - a significant issue from the point of view of the history of hermetic literature - he was the first to cite the tractate Asclepius, ${ }^{134}$ which is supposed to have been known to him in Greek, that is in the original, Logos Teleios - as he himself mentions: "in eo enim libro qui lógos téleios inscribitur . .." (Div. inst. 7.18.3); for, in a passage later, Lactantius quotes a fragment from that work in actual ancient Greek (see Div. inst. 7.18.3-4 ${ }^{135}$ ).

One of the main motifs addressed in hermetic literature is the issue of man as a unique "twofold" construct (homo duplicis naturae). In this aspect, the representative excerpt, to a certain extent combining the idea or the characteristic quality of human nature from the hermetic perspective, seems to be the $F H 15$ (=Div. inst. 7.13 .3$)^{136}$ by Lactantius:

Hermes, describing the nature of man, that he might show how he was made by God, introduced this statement: "And the same out of two natures - the immortal and the mortal — made one nature, that of man, making the same partly immortal, and partly mortal; and bringing this, he placed it in the midst, between that nature which was divine and immortal, and that which was mortal and changeable, that seeing all things, he may admire all things."137

The above hermetic content quoted by Lactantius (with the words of Hermes - "And the same out of two natures. . . he may admire all things"-provided by the author in Greek) seems to be an essence/synthesis and at the same time a paraphrase of several fragments drawn from the tractate Asclepius and

131 The issue of the relationship between Christian theology and hermetic theological discourse in light of the oeuvre by Lactantius was discussed in more detail in: E.D. Digeser, The Making of a Christian Empire: Lactantius \& Rome (Ithaca: Cornell University Press 2000) 65-90.

132 See Litwa, Hermetica II, 183.

133 Div. inst. 1.11.61 ( $\rightarrow$ CH 10.5); Div. inst. 2.15.6, 5.14.11 ( $\rightarrow$ CH 9.4); Div. inst. 6.25.10 $(\rightarrow C H$ 12.23); Div. inst. 2.15.7 ( $\rightarrow$ CH 16.15-16). See Litwa, Hermetica II, 183, f.n. 4.

134 Div. inst. $4.6 .4(\rightarrow$ Ascl. 8); Div. inst. 7.9.11 $(\rightarrow$ Ascl. 11); Div. inst. $2.15 .8(\rightarrow$ Ascl. 25$)$; Div. inst. 4.6.9,7.18.3-4 and Epit. 66.6 ( $\rightarrow$ Ascl. 26); Div. inst. 2.14.6 ( $\rightarrow$ Ascl. 28); Div. inst. 2.15.6 $(\rightarrow$ Ascl. 29); Div. inst. 6.25.10-11 ( $\rightarrow$ Ascl. 41). See Litwa, Hermetica II, 183, f.n. 5, and Das Corpus Hermeticum Deutsch (trans. J. Holzhausen) (Stuttgart - Bad Cannstatt: Frommann 1997) I-II; A. Löw, Hermes Trismegistos als Zeuge der Wahrheit. Die christliche Hermetikrezeption von Athenagoras bis Laktanz (Theophaneia 36; Berlin: Philo 2002); A. Wlosok, Laktanz und die philosophische Gnosis. Untersuchungen zu Geschichte und Terminologie der gnostischen Erlösungsvorstellung (Heidelberg: Winter 1960).

135 See Scott, Hermetica IV, 26-27, see also: Litwa, Hermetica II, 183, f.n. 5.

136 Cf. also: $F H$ 8a-b (=Div. inst. 2.10.14 i 7.4.3) and FH 14 (=Div. inst. 7.9.11).

137 English translation in: Lactantius, The divine institutes, 316; http://www.ccel.org/ccel/schaff/anf07. html[access: 17.08.2020]; cf. also: Litwa, Hermetica II, 192. 
the compilation Corpus Hermeticum, presenting analogical statement pertaining to the construct that a human being is:

\begin{tabular}{|c|c|}
\hline Hermetica $a^{138}$ & FH 15 (=Div. inst. 7.13.3) $)^{139}$ \\
\hline $\begin{array}{l}\text { Ascl. 7: Mankind is the only living thing that } \\
\text { is twofold: one part of him is simple, what } \\
\text { the Greeks call ousiódēs, what we call a form } \\
\text { of divine likeness. What the Greeks call hylikós } \\
\text { and we call earthly is fourfold. From it is made } \\
\text { the body that covers over what we have already } \\
\text { termed divine in mankind [...]. }\end{array}$ & $\begin{array}{l}\text { And the same out of two natures-the immor- } \\
\text { tal and the mortal-made one nature, that of } \\
\text { man, making the same partly immortal, and } \\
\text { partly mortal; and bringing this, he placed it in } \\
\text { the midst, between that nature which was divi- } \\
\text { ne and immortal, and that which was mortal and } \\
\text { changeable [...]. }\end{array}$ \\
\hline $\begin{array}{l}\text { Ascl. 8: Then, so great and good was he (i.e. god) } \\
\text { that he wanted there to be another to admire } \\
\text { the one (i.e. the world) he had made from him- } \\
\text { self, and straightaway he made mankind, imi- } \\
\text { tator of his reason and attentiveness. [...] After } \\
\text { he }<\text { had made }>\text { mankind ousiódēs and noticed } \\
\text { that he could not take care of everything un- } \\
\text { less he was covered over with a material wrap- } \\
\text { ping, god covered him with a bodily dwelling } \\
\text { and commanded that all humans be like this, } \\
\text { mingling and combining the two natures into } \\
\text { one in their just proportions. Thus god shapes } \\
\text { mankind from the nature of soul and body, } \\
\text { from the eternal and the mortal, in other words, } \\
\text { so that the living being so shaped can prove } \\
\text { adequate to both its beginnings, wondering at } \\
\text { heavenly beings and worshipping them, ten- } \\
\text { ding earthly beings and governing them. }\end{array}$ & $\begin{array}{l}\text { And the same out of two natures-the immor- } \\
\text { tal and the mortal-made one nature, that of } \\
\text { man, making the same partly immortal, and } \\
\text { partly mortal; and bringing this, he placed it in } \\
\text { the midst, between that nature which was di- } \\
\text { vine and immortal, and that which was mortal } \\
\text { and changeable, that seeing all things, he may } \\
\text { admire all things. }\end{array}$ \\
\hline $\begin{array}{l}\text { Ascl. 9: Mankind is a living thing, then, but } \\
\text { none the lesser for being partly mortal; indeed, } \\
\text { for one purpose his composition seems perhaps } \\
\text { fitter and abler, enriched by mortality. Had he } \\
\text { not been made of both materials, he would not } \\
\text { have been able to keep them both, so he was } \\
\text { formed of both, to tend to earth and to cherish } \\
\text { divinity as well. }\end{array}$ & $\begin{array}{l}\text { And the same out of two natures-the immor- } \\
\text { tal and the mortal-made one nature, that of } \\
\text { man, making the same partly immortal, and } \\
\text { partly mortal; and bringing this, he placed it in } \\
\text { the midst, between that nature which was di- } \\
\text { vine and immortal, and that which was mortal } \\
\text { and changeable, that seeing all things, he may } \\
\text { admire all things. }\end{array}$ \\
\hline
\end{tabular}

138 English translation in: Copenhaver, Hermetica, 70 (Ascl. 7); 71 (Ascl. 8); 72 (Ascl. 9); 72-73 (Ascl. 10); 80 (Ascl. 22); 3 (CH 1.15); 15(CH 4.2).

139 English translation in: Lactantius, The divine institutes, 316; cf. also: Litwa, Hermetica II, 192. 


\begin{tabular}{|c|c|}
\hline Hermetica $a^{138}$ & FH 15 (=Div. inst. 7.13.3) $)^{139}$ \\
\hline $\begin{array}{l}\text { Ascl. 10: [...] (god) has two images, world and } \\
\text { mankind. Whence, though mankind is an in- } \\
\text { tegral construction, it happens that in the part } \\
\text { that makes him divine, he seems able to rise } \\
\text { up to haeven, as if from higher elements-soul } \\
\text { and consciousness, spirit and reason. But in his } \\
\text { material part-consisting of fire <and earth,> } \\
\text { water and air-he remains fixed on the ground, } \\
\text { a mortal, lest he disregard all the terms of his } \\
\text { charge as void and empty. Thus, humankind is } \\
\text { divine in one part, in another part mortal, resi- } \\
\text { ding in body. }\end{array}$ & $\begin{array}{l}\text { And the same out of two natures-the immor- } \\
\text { tal and the mortal-made one nature, that of } \\
\text { man, making the same partly immortal, and } \\
\text { partly mortal; and bringing this, he placed it in } \\
\text { the midst, between that nature which was divi- } \\
\text { ne and immortal, and that which was mortal and } \\
\text { changeable }[. . .] \text {. }\end{array}$ \\
\hline $\begin{array}{l}\text { Ascl. 22: [...] god made mankind good and ca- } \\
\text { pable of immortality through his two natures, } \\
\text { divine and mortal, and so god willed the ar- } \\
\text { rangement whereby mankind was ordained to } \\
\text { be better than the gods, who were formed only } \\
\text { from the immortal nature, and better than all } \\
\text { other mortals as well. }\end{array}$ & $\begin{array}{l}\text { And the same out of two natures - the immor- } \\
\text { tal and the mortal-made one nature, that of } \\
\text { man, making the same partly immortal, and } \\
\text { partly mortal; and bringing this, he placed it in } \\
\text { the midst, between that nature which was divi- } \\
\text { ne and immortal, and that which was mortal and } \\
\text { changeable }[. . .] \text {. }\end{array}$ \\
\hline $\begin{array}{l}\mathrm{CH} \text { 1.15: }[\ldots] \text { unlike any other living thing } \\
\text { on earth, mankind is twofold-in the body } \\
\text { mortal but immortal in the essential man } \\
\text { [ousióde ánthrōpon]. }\end{array}$ & $\begin{array}{l}\text { And the same out of two natures - the immortal } \\
\text { and the mortal-made one nature, that of man, } \\
\text { making the same partly immortal, and partly } \\
\text { mortal }[\ldots] \text {. }\end{array}$ \\
\hline $\begin{array}{l}\mathrm{CH} \text { 4.2: The man became a spectator [theatés }] \\
\text { of god's work. He looked at it in astonishment } \\
\text { and recognized its maker. }\end{array}$ & $\begin{array}{l}{[\ldots] \text { that seeing all things, he may admire }} \\
\text { all things. }\end{array}$ \\
\hline
\end{tabular}

Thus, we are able to observe that owing to his twofold nature, man takes an intermediary position: between the pure divinity and the (loathed as impure) earthly component. Man is situated in an ideal position to be loved by God, having the inherent divine element, and to himself love the lower beings, due to his own material form.

I discussed the issues pertaining to anthropology (and to be more precise: to anthropogony), discovered in hermetic literature, in a chapter of my book on medieval and renaissance Hermetism. ${ }^{140}$ To wit, according to hermetic anthro-

140 See Sowińska, Hermetica [part I, the chapter: "Bóg stwórcą człowieka"] 64-81. The argument that follows, i.e. on the tenets of hermetic anthropology was crated particularly on the basis of the chapter "Bóg stwórcą człowieka," which constitutes a discussion of such anthropology in terms of the motif of man in the tractate Ascelpius. The anthropological elements to be found in the compilation Corpus Hermeticum are analysed in part II of the book (with each respective piece, and hence also chapter) 
pogony, God, having created the second, visible god (=the world), that he saw as perfect and praiseworthy, desired to bring to life another being, one that would be able to perceive the beauty of the world. Thus, man was born, an intelligent being (the philosophy of hermeticism does allow exceptions with regard to that, i.e. the lack of noûs). In hermetic view, man distinguishes himself from other living creature with his twofold nature (as underscored by Lactantius in the fragment cited). He is constructed of the pars simplex, known in Greek as ousiṓdès, that is the divine part, and the pars quadruplex, in Greek hylikós, of a fourfold structure (comprising fire, water, air, and earth), and related to the worldly (earthly/corporeal) sphere, concealing the divine. Having initially created man in a simple simplex (divine) form, God realised that in such a form the newly created being would not be able to perform the task intended for it. Hence, the Creator clothed it in matter (flesh). As precisely such an aggregate, the "twofold" man was able to fulfil God's will, and most of all to worship Him, remembering that - just like the world - he, too, is an image of Him. And thus, God created man of soul and body, that is of the eternal and of the mortal nature, ${ }^{141}$ so that, as a being created in such a manner, he could worship all that is eternal and celestial, and rule over the earthly creatures. In order to constitute a whole, man comprises four elements, both in the material and in the spiritual aspect. For he possesses two pairs of limbs, that he uses to serve the lower (earthly) world, and four elements: the mind (lit. animus), consciousness (sensus), memory (memoria), the ability to anticipate (providentia), thanks to which he is able to recognise all the divine

pertaining stricte to this body of texts (pp. 99-192), and due to the subject matter had to be used here as well. The motif of man in Hermetism was synthetically addressed also by: C. Moreschini and R. van den Broek - see C. Moreschini, Hermes Christianus. The Intermingling of Hermetic Piety and Christian Thought (trans. P. Baker) (Turnhout: Brepols 2011) 15-16; Broek, "Hermeticism," s.v.

141 One has to consider the mythological account of creation of a twofold man, that we can find in $\mathrm{CH} 1$ (titled Poimandres). According to the myth presented there, God (Reason, i.e. Noûs), that is the father of all beings, being "life" ( $d z \bar{o} \bar{e})$ and "light" (phôs), gave birth to Man (a primeval man, however, i.e. homo substantialis), extremely beautiful, and bearing marks of the image of his Father - God. The primeval man became passionate about mindless Nature (most probably as a result of narcissistic love for his own body, as he was able to see his reflection in the water). It is then that the being (human) of a twofold nature (at the same time immortal and mortal) was created. The one who got to know himself (i.e. who understood his actual immortality) attained good, as opposed to the one who bound his entire life with corporality, wordiness, for he-according to hermetic philosophy - has remained in the darkness and is wandering, subject tu sensual suffering (incl. death). The bodily component of man (the focus on the hylic aspect, encompassing also the desire) poses a threat to the intelligible component in human. If, on the other hand - paraphrasing a passage from the dialogue - man understands that he consists of "life" and "light" (the "light" giving his reason [noûs], the "life"- his soul [psychế], who are, or at least should be, a component of every human being, as man is not always provided with noûs) and that he has originated from such components, then he will return to life, because "light" and "life" constitute divine components, of which the primeval, and hence pure, unblemished Man was born. Only the soul of a pious person - as van den Broek concludes - who got to know himself and God, may, according to hermeticists, avoid the yoke of matter and return to his initial divine position. See Broek, "Hermetism," 564. 
things and admire them. "The great miracle" that the man is, means a creature worth praise and honours: "magnum miraculum est homo, animal adorandum et honorandum" (Ascl. 6); hence, he is: thaûma thaumasiôtaton (CH 1.16) - an extremely wonderful object (worth) of admiration. ${ }^{142}$ However, man has to remember that the material, i.e. external part of his existence, is obviously far inferior to the divine form that he guards inside, and for that reason he should loathe whatever the bodily urge, cupiditas corporalis, imposes upon him. The measure (and the goal) of man according to the principles of hermetic philosophy is therefore religiosity, and that aspect Lactantius considered to be the ideal of piety that he could "transfer" to the realm of Christianity. ${ }^{143}$ In line with hermetic anthropology, man was created for the purpose of admiring the world created by God, while the primary task of human being is to praise his Creator. And because every creature, according to the tenets of Hermetism, is supposed to possess an element of its Creator, in this context one may regard the thesis of extending respect to every creature (and hence to God). This relationship, combined with an element of pantheism, is illustrated perfectly in $\mathrm{CH} 5$, where we can read that, willing to see (intelligible) God, we ought to look at the stars in the sky, maintained in an appropriate order, at the Sun, the greatest celestial deity, superior to the earth and the sea, that is surrounded by numerous smaller stars. We ought to wonder: who determines the movements of the respective stars, with each advancing differently? whose hand is at the helm of the "instrument" that is the Ursa (Maior and Minor), spinning around and drawing the world with it? who delineated the boundaries of the seas and made Earth firm? The answer to all the above questions is: God-(their) Creator (poiētếs) and Lord (despótēs). It is the same causative force that shapes man in woman's womb, and grants him a beautiful appearance; it shapes the eyes, the nose, the ears, and opens the mouth; it weaves the tendons, clears out veins, and solidifies bones, as we read in $\mathrm{CH}$ 5; it stretches the skin around the viscera, and separates the fingers (and toes) from one another, it flattens the feet; it carves pores in the skin, and stretches the spleen; it gives the heart its shape of a pyramid. ${ }^{144}$ That was the content that also Lactantius was said to allude to in $F H 8 \mathrm{a}=$ Div. inst. 2.10 .4 (cf. also: $F H 8 \mathrm{~b}=$ Div. inst. 7.4.3), where it is said that "Hermes, ... not only said that humanity was made by God [a deo] in the image of God [ad imaginem dei], but also tried to explain how, by

142 R. van den Broek suggests to take the Greek phrase thaûma thaumasiốtaton in $\mathrm{CH} 1.16$ as the foundation of the phrase: magnum miraculum in Ascl. 6. See Broek, "Hermetism," 562-563; cf. T. Petersen, "Why «wonder»? A Discussion of the Anthropology of Poimandres (CH I) and How to Read It," SMSR 83/1 (2017) [Hermetic Texts in Antiquity] 61-74.

143 See Litwa, Hermetica II, 182.

144 See CH 5.6 and Sowińska, Hermetica, 130-131. 
complex reasoning, God formed each part of the human body - not a single part any less valuable for its necessary utility than for its beauty." 145

According to the assumptions of Hermetism pertaining to creation, every created being has its own father. There is nothing in the world that the Creator would not be; He is what exists, and what does not-with the difference being that the things that exist were placed by God "in the light of day," whereas those that do not exist, he concealed within Himself. The Creator can be recognised with the mind, but also perceived with the eyes, he is both bodiless and concurrently many-bodied (or all-bodied) (multicorporeus/pantosốmatos), for he is to be found in every body. Trismegistus draws our attention particularly to the fact that such elements as the universe and man could not have been born without an intervention of a greater (external) power - without God. And God, as a Craftsman, is contained in everything he brought to life, because $\mathrm{He}$ is its author and, according to Trismegistus, manifests himself precisely in the creation of the macro- and microcosm, that is of the world and man. ${ }^{146}$

\section{Final Remarks}

Lactantius, using one of hermetic fragments that he includes in his Divinae institutiones, addresses the notion crucial for hermetic anthropology: the twofold components in man, specific for him only, and conditioning his participation both in the divine and in the earthly sphere. The gnome of unique nature of man ("solum animal homo duplex est" [Ascl. 7]) defines the entire approach of hermetic philosophy to the issue of man's situation in the world. Man, despite his hylic shell, and hence an imperfect creation (though with regard to that the hermetic message is not uniform), is a divine creature (ánthrōpos dzōión esti theîon-CH 10.24), because of his characteristics, typical solely of mankind, and is even referred to as a "mortal god" (theòs thnètós - CH 10.24).

The fact that Lactantius imposes upon hermetic texts, and thus upon Trismegistus himself, a Christian integumentum may find explanation, for instance, in the common in fourth century $\mathrm{AD}$ equally Christological exegesis of the Old Testament; anyway, no discrepancies are to be discovered in the method of interpreting those texts at the time. ${ }^{147}$ The Christian perception (understanding) of the essence of God in the first centuries after Christ, draws largely upon Platonic principles, a fact that had a significant impact on the awareness of common

\footnotetext{
145 English translation in: Litwa, Hermetica II, 188.

146 See A. Sowińska, Hermetica 131.

147 Broek, "Hermetism," 569.
} 
elements between Christianity and Hermetism, seen as a melting pot of sorts amalgamating Platonic, stoic, Jewish and Egyptian influences, though the range of the latter has been the subject of contention among contemporary scholars. The congruence of both these systems - of Christianity and Hermetism - on the doctrinal, incl. rhetoric, level had not gone unnoticed by Christian writers who made efforts to demonstrate that the assumptions apparent in the Christian religion date back to the time before Christ, thus being "eternal" 148 - the notion was to also extend its influence on the interpretation of hermetic texts in the era of late Middle Ages and in modernity, as a testament to that one can consider the catalogue of the so-called prisci theologi, the number of whom included, inter alios, Hermes Trismegistus and Plato.

\section{Bibliography}

Adler, A. (ed.), Suidae Lexicon (Stuttgart: Teubner 1967) I-V.

Affifi, A.E., "The Influence of Hermetic Literature on Moslem Thought," Bulletin of the School of Oriental and African Studies 13/4 (1951) 840-855.

Albertus Magnus, De animalibus libri XX.И, nach der Cölner Urschrift (ed. H. Stadler) (Münster: Aschendorff 1916-1921) I-II.

Albertus Magnus, De intellectu et intelligibili (ed. A. Borgnet) (B. Alberti Magni Opera Omnia 9; Paris: Vivès 1890).

Albertus Magnus, De somno et vigilia (ed. A. Borgnet) (B. Alberti Magni Opera Omnia 5; Paris: Vivès 1890).

Albertus Magnus, Ethicorum libri X (ed. A. Borgnet) (B. Alberti Magni Opera Omnia 7; Paris: Vivès 1891).

Albertus Magnus, Liber de causis et processu universitatis (ed. A. Borgnet) (B. Alberti Magni Opera Omnia 10; Paris: Vivès 1891).

Albertus Magnus, Mineralium libri quinque (ed. A. Borgnet) (B. Alberti Magni Opera Omnia 5; Paris: Vivès 1890).

Alpers, K., "Untersuchungen zum griechischen Physiologus und den Kyraniden," Vestigia Bibliae 6 (1984) 13-87.

Athenagoras, Legatio pro Christianis (ed. M. Marcovich) (Berlin: de Gruyter 1990).

Barwick, Ch. - Kūhnert, F. (eds.), Flavii Sosipatri Charisii Artis grammaticae libri V (Stuttgart: Teubner 1997).

Beatrice, P.F.: Anonymi Monophysitae theosophia. An Attempt at Reconstruction (Leiden: Brill 2001). Bidez, J. - Cumont, F., Mages hellénisés: Zoroastre, Ostanès et Hystaspe d'après la tradition grecque (Paris: Belles Lettres 1938) I-II.

van Bladel, K., "Sources of the Legend of Hermes in Arabic," Hermetism from Late Antiquity to Humanism / La tradizione ermetica dal mondo tardo-antico all'Umanesimo. Atti del Convegno

148 Cf. Broek, "Hermetism," 568. 
internazionale di studi, Napoli, 20-24 novembre2001 (eds. P. Lucentini - I. Parri - V. Perrone Compagni) (Turnhout: Brepols 2003) 285-293.

van Bladel, K., The Arabic Hermes: From Pagan Sage to Prophet of Science (New York: Oxford University Press 2009).

Braun, R. (ed.), Opera Quodvultdeo Carthaginiensi episcopo tributa (CCSL 60; Turnhout: Brepols 1976).

Brock, S., "Some Syriac Excerpts from Greek Collection of Pagan Prophecies," Vigiliae Christianae 38 (1984) 77-90

Brock, S., "A Syriac Collection of Prophecies of the Pagan Philosophers," Orientalia Lovaniensia Periodica 14 (1983) 203-246.

van den Broek, R., "Gnosticism and Hermetism in Antiquity. Two Roads to Salvation," Gnosis and Hermeticism. From Antiquity to Modern Times (eds. R. van den Broek - W.J. Hanegraaff) (Albany, NY: State University of New York 1998) 1-20.

Bull, Ch., The Tradition of Hermes Trismegistus (Leiden: Brill 2018).

Burnett, Ch., "The Legend of the Three Hermes and Abū-Ma'shar's Kitab al-Ulüf in the Latin Middle Ages," Journal of the Warburg and Courtauld Institutes 39 (1976) 231-234.

C. Marius Victorinus, Commenta in Ciceronis Rhetorica accedit incerti auctoris tractatus de attributis personae et negotio (red. T. Riesenweber) (BSGRT; Berlin: de Gruyter 2013).

Campbell, P. (ed.), The Complete Works of Saint Cyprian of Carthage (Merchantville, NJ: Evolution 2013).

Castelli, E., "Saggio introduttivo: L'Elenchos, ovvero una 'biblioteca' contro le eresie," 'Ippolito'. Confutazione di tutte le eresie (red. A. Magris) (Brescia: Morcelliana 2012) 21-56.

Chabot, I.-B. (ed.), Iacobi Edesseni Hexaemeron seu in opus creationis libri septem (CSCO; Scriptores Syri 56; Paris: Typographeo Reipublicae 1928).

Copenhaver, B., Hermetica. The Greek Corpus Hermeticum and the Latin Asclepius in a New English Translation, with Notes and Introduction (Cambridge: Cambridge University Press 1992).

Das Corpus Hermeticum Deutsch (trans. J. Holzhausen) (Stuttgart - Bad Cannstatt: Frommann 1997) I-II.

Delatte, L., Textes latins et vieux français relatifs aux Cyranides (Paris: Droz 1942).

Dennis, G.T. (ed.), Michaelis Pselli Orationes forenses et acta (Leipzig: Teubner 1994).

Didymos der Blinde, Kommentar zum Ecclesiastes (Tura Papyrus). III. Kommentar zu EcclesiastesKap. 5 und 6 (eds. L. Koenen - J. Kramer) (Bonn: Habelt 1970).

Didymos der Blinde, Psalmenkommentar (Tura Papyrus). II. Kommentar zu Psalm 22-26, 10 (ed. M. Gronewald) (Bonn: Habelt 1968).

Digeser, E.D., The Making of a Christian Empire: Lactantius \& Rome (Ithaca: Cornell University Press 2000).

Dillon, J.M. (ed.), Iamblichi Chalcidensis In Platonis Dialogos Commentariorum Fragmenta (Philosophia Antiqua 23; Leiden: Brill 1973).

Dodge, B., The Fihrist of al-Nadīm. A Tenth-century Survey of Muslim Culture (New York: Columbia University Press 1970) I-II.

Dombart, B. - Kalb, A. (eds.), Sancti Aurelii Augustini De civitate Dei (CCSL 47; Turnhout: Brepols 1955).

Duffy, J.M. - O’Meara, D.J. (ed.), Michaelis Pselli Philosophica minora (Leipzig: Teubner 1992) I-II.

Duffy, J.M. - Westerink, L.G. (eds.), Michaelis Pselli Theologica (Munich - Leipzig: Teubner 2002) II. 
Eusèbe de Césarée, La Préparation Évangelique (Introduction, texte grec, traduction et commentaire par J. Sirinelli - É. des Places) (SC 206; Paris: Cerf 1974) I.

Eusèbe de Césarée, La Préparation Évangelique (Introduction, traduction et notes par G. Schroeder-É. des Places; texte grec révisé par É. des Places) (SC 369; Paris: Cerf 1991) VIII-IX-X.

Faivre, A., "Renaissance Hermeticism and the Concept of Western Esotericism," Gnosis and Hermeticism. From Antiquity to Modern Times (eds. R. van den Broek - W.J. Hanegraaff) (Albany, NY: State University of New York 1998) 109-123.

Festugière, A.-J. - Nock, A.D. (eds.), Hermès Trismégiste. Corpus Hermeticum. I. Poimandres, Traités II-XII. II. Corpus Hermeticum. Tome XIII-XVIII. Asclepius. III. Fragments Extraits de Stobée (I-XXII). IV. Fragments Extraits de Stobée (XXIII-XXIX); Fragments Divers (Paris: Belles Lettres 2007-2011), 1 ed. (Paris: Belles Lettres 1946-1954) I-IV.

Festugière, A.-J., La Révélation d'Hermes Trismégiste. I. L'Astrologie et les Sciénces Occultes (Paris: Gabalda 1950).

Fowden, G., The Egyptian Hermes. A Historical Approach to the Late Pagan Mind (Cambridge: Cambridge University Press 1986).

Fredouille, J.-C. (ed.), Tertullien. Contre les Valentiniens (SC 280, Paris: Cerf 1980) I.

Friedrich, H.-V. (ed.), Thessalos von Tralles griechisch und lateinisch (Meisenheim am Glan: Hain 1968).

Gautier, P. (ed.), Michaelis Pselli Theologica (Munich - Leipzig: Teubner 2002) I.

Goold, G.P. (ed.), M. Manilii Astronomica (Stuttgart - Leipzig: Teubner 1998).

Green, T.M., The City of the Moon God. Religious Traditions of Harran (Leiden: Brill 1992).

Gregoire de Nazianze, Discours 27-31 (Discours theologiques) (ed. P. Gally) (SC 250; Paris: Cerf 1978).

Halleux, R., "The Reception of Arabic Alchemy in the West," Encyclopedia of the History of Arabic Science (ed. R. Rashed) (London: Routledge 1996) I-III.

Hanegraaff, W.J. (ed.), Dictionary of Gnosis and Western Esotericism (Leiden - Boston, MA: Brill 2006).

Heck, E. - Wlosok, A. (eds.), L. Caeli Firmiani Lactanti Epitome Divinarum institutionum (BSGRT; Stuttgart - Lepizig: Teubner 1994).

Henrichs, A. - Preisendanz, K. (eds.), Papyri Graecae Magicae. Die griechischen Zauberpapyri (München: Saur 2001) I-III.

Hermes Trismegistus, Liber viginti quattuor philosophorum (ed. F. Hudry) (Turnhout: Brepols 1997).

[Hermes Trismegistus], "Liber de stellis beibeniis. Textus Arabicus et translatio Latina," Hermetis Trismegisti astrologica et divinatoria (eds. G. Bos et al.) (Turnhout: Brepols 2001) 9-99.

[Hermes Trismegistus], Le livre des XXIV philosophes. Résurgence d'un texte du IVe siècle (ed. F. Hudry) (Paris: Vrin 2009).

Hermias Alexandrinus, In Platonis Phaedrum scholia (eds. C.M. Lucarini - C. Moreschini) (Berlin - Boston, MA: de Gruyter 2012).

Heylen, F. (ed.), Filastrii episcopi Brixiensis Diversarum hereseon liber (CCSL 9; Turnhout: Brepols 1957).

Hippolytus, Refutatio omnium haeresium (ed. M. Marcovich) (Berlin: de Gruyter 1986).

Hoffmann, E. - Klibansky, R. (eds.), Nicolai de Cusa Opera omnia. I. De docta ignorantia (Leipzig: Meiner 1932). 
Hudry F., "Le De secretis naturae du pseudo-Apollonius de Tyane: Traduction latine par Hugues de Santalla du Kitâb sirr al-halîqa de Balînnûs," Chrysopoeia 6 (1997-1999) 1-154.

Iamblichus, De mysteriis (eds. E.C. Clark - J.M. Dillon - J.P. Hershbell) (WGRW 4; Atlanta, GA: SBL 2003).

Ioannis Antiocheni Fragmenta ex Historia chronica (Introduzione, edizione critica e traduzione a cura di U. Roberto) (Texte und Untersuchungen zur Geschichte der altchristlichen Literatur 154; Berlin: de Gruyter 2005).

Jamblique, Les mystères d'Égypte (ed. É. des Places) (Paris: Belles Lettres 1989).

Kaimakis, D. (ed.), Die Kyraniden (Meisenheim am Glan: Hain 1976).

Kotter, P.B. (ed.), Die Schriften des Johannes von Damaskos. V. Opera homiletica et hagiographica (Patristische Texte und Studien 29; Berlin: de Gruyter 1988).

Kunitzsch, P., "Origin and History of Liber de stellis beibeniis," Hermetism from Late Antiquity to Humanism / La tradizione ermetica dal mondo tardo-antico all'Umanesimo. Atti del Convegno internazionale di studi, Napoli, 20-24 novembre 2001 (eds. P. Lucentini - I. Parri - V. Perrone Compagni) (Turnhout: Brepols 2003) 449-460.

Kyrill von Alexandrien, Gegen Julian. I. Buch 1-5 (ed. Ch. Riedweg) (Die Griechischen Christlichen Schriftsteller der ersten Jahrhunderte, Neue Folge 20; Berlin: de Gruyter 2016).

Kyrill von Alexandrien, Gegen Julian. II. Buch 6-10 und Fragmente (eds. W. Kinzig - Th. Brüggemann) (Die Griechischen Christlichen Schriftsteller der ersten Jahrhunderte, Neue Folge 21; Berlin: de Gruyter 2017).

L. Caelius Firmianus Lactantius, Divinarum institutionum libri septem (eds. E. Heck - A. Wlosok) (BSGRT; Berlin: de Gruyter 2005-2007) I-II.

Lactance, Épitomé des Institutions Divine (ed., trans. M. Perrin) (SC 335; Paris: Cerf 1992).

Lactance, Institutions divers livre (ed. P. Monat) (SC 277; Paris: Cerf 1992) IV.

Lactantius, The divine institutes, http://www.ccel.org/ccel/schaff/anf07.html [access: 17.08.2020].

von Lieven, A., "Thot selbdritt. Mögliche ägyptische Ursprünge der arabisch-lateinischen Tradition dreier Hermesgestalten," Die Welt des Orients 37 (2007) 69-77.

Lindsay, W.M. (ed.), Isidori Hispalensis Episcopi Etymologiarum sive Originum libri XX (Oxford: Clarendon Press 1911) I-II.

Litwa, M.D., Hermetica II. The Excerpts of Stobaeus, Papyrus Fragments, and Ancient Testimonies in an English Translation with Notes and Introduction (Cambridge: Cambridge University Press 2018).

Litwa, M.D., Refutation of All Heresies: Translated with an Introduction and Notes (WGRW 40; Atlanta, GA: SBL 2016).

Logan, A.H.B., "Marcellus of Ancyra (Pseudo-Anthimus), 'On the Holy Church': Text, Translation, and Commentary," Journal of Theological Studies 51 (2000) 81-112.

Lopilato, R., The Apotelesamtika of Manetho (Dys. Brown University 1998).

Löw, A., Hermes Trismegistos als Zeuge der Wahrheit. Die christliche Hermetikrezeption von Athenagoras bis Laktanz (Theophaneia 36; Berlin: Philo 2002).

Lucentini, P. - Perrone Compagni, V., I testi e i codici di Ermete nel Medioevo (Firenze: Polistampa 2001).

Lucentini, P., Liber Alcidi de immortalitate animae: Studio e edizione critica (Naples: Istituto Universitario Orientale 1984).

Marchesi, C. (ed.), Arnobii Adversus nationes libri VII (Corpus scriptorum Latinorum Paravianum; Torino: Battista 1953) 
Mitchell, C.W., S. Ephraim 's Prose Refutations of Mani, Marcion, and Bardaisan (London: Williams $\&$ Norgate 1921) I-II.

Moreschini, C., Hermes Christianus. The Intermingling of Hermetic Piety and Christian Thought (trans. P. Baker) (Turnhout: Brepols 2011).

Mosshammer, A.A. (ed.), Georgii Syncelli Ecloga chronographica (BSGRT; Leipzig: Teubner 1984).

Moyer, I.S., "A Revised Astronomical Dating of Thessalus's De virtutibus herbarum," The Frontiers of Ancient Science: Essays in Honor of Heinrich von Staden (ed. B. Holmes) (Berlin: de Gruyter 2015) 437-450.

van Oort, J., "Augustine and Hermes Trismegistus: An Inquiry into the Spirituality of Augustine's «Hidden Years»," Journal of Early Christian History 6 (2016) 55-76.

Pappacena, M., "La figura di Ermete Trismegisto nella tradizione Araba," Hermetism from Late Antiquity to Humanism / La tradizione ermetica dal mondo tardo-antico all'Umanesimo. Atti del Convegno internazionale di studi, Napoli, 20-24 novembre 2001 (eds. P. Lucentini - I. Parri V. Perrone Compagni) (Turnhout: Brepols 2003) 263-283.

Pease, A.S. (ed.), M. Tulli Ciceronis De natura deorum (Cambridge, MA: Harvard University Press 1955-1958) I-II.

Peters, F.E., "Hermes and Harran. The Roots of Arabic-Islamic Occultism," Intellectual Studies on Islam (eds. M.M. Mazzaou - V.B. Moreen) (Salt Lake City, UT: University of Utah 1990) 185-215.

Petersen, T., "Why «wonder»? A Discussion of the Anthropology of Poimandres (CH I) and How to Read It," Studi a Materiali di Storia delle Religioni 83/1 (2017) 61-74.

Picatrix: Un traité de magie médiéval (trans., introduction and commentary B. Bakhouche et al.) (Turnhout: Brepols 2003).

Pingree, D. (ed.), Dorothei Sidonii Carmen Astrologicum. Interpretationem Arabicam in linguam Anglicam versam una cum Dorothei fragmentis et Graecis et Latinis (BSGRT; Stuttgart: Teubner 1976).

Pingree, D., "Some of the Sources of the Ghāyat al-Hakīm," Journal of the Warburg and Courtauld Institutes 43 (1980) 1-15.

Pingree, D., "The Sābians of Harrān and the Classical Tradition," International Journal of the Classical Tradition 8 (2002) 8-35.

Pingree, D., Picatrix: The Latin Version of the Ghāyat Al-Hakim (London: Warburg Institute 1986).

Plessner, M., "Hermes Trismegistus and Arab Science," Studia Islamica 2 (1954) 45-59.

Ruska, J., Tabula Smaragdina. Ein Beitrag zur Geschichte der hermetischen Literatur (Heidelberg: Winter 1926).

Ruska, J., "Zwei Bücher de Compositione Alchemiae und ihre Vorreden," Archiv für Geschichte der Mathematik, der Naturwissenschaften und der Technik 11 (1928) 28-37.

Scott, W., Hermetica. The Ancient Greek and Latin Writings which Contain Religious or Philosophic Teachings Ascribed to Hermes Trismegistus. I. Introduction, Texts and Translation. II. Notes on the Corpus Hermeticum. III. Notes on the Latin Asclepius and the Hermetic excerpts of Stobaeus. IV. Testimonia, Addenda and Indices (Boston, MA: Shambhala 1985), 1 ed. (Oxford: Clarendon Press 1924-36) I-IV.

Senger, H.G. - Bormann, K. (eds.), Nicolai de Cusa Opera omnia. XI.1. De beryllo (Hamburg: Meiner 1988).

Seyfarth, W. (ed.), Ammiani Marcellini rerum gestarum libri qui supersunt (Leipzig: Teubner 1999) I-II. 
Sowińska, A., Hermetica średniowiecza i renesansu. Studium z historii myśli europejskiej, (Katowice: Wydawnictwo Uniwersytetu Śląskiego 2018).

Stavenhagen, L., "The Original Text of the Latin Morienus," Ambix: The Journal of the Society for the Study of Alchemy and Early Chemistry 17 (1970) 1-12.

Stone, R. - West, Ch. (trans.), The Divorce of King Lothar and Queen Theutberga: Hincmar of Rheims's „De Divortio” (Manchester: Manchester University Press 2016).

Tarrant, H. (ed.), Thrasyllan Platonism (Ithaca: Cornell University Press) 1993.

Thurn, I. (ed.), Ioannis Malalae Chronographia (CFHB 35; Berlin: de Gruyter 2000).

Vaschalde, A. (ed.), Iacobi Edesseni Hexaemeron seu in opus creationis libri septem (CSCO 97; Scriptores Syri 48; Leuven: Durbecq 1953).

Waley Singer, D. - Steele, R., "The Emerald Table," Proceedings of the Royal Society of Medicine. Section of the History of Medicine 21 (1927) 485-501.

Waszink, J.H. (ed.), Quinti Septimi Florentis Tertulliani “De anima” (Leiden: Brill 2010).

Weisser, U., Das "Buch über das Geheimnis der Schöpfung” von Pseudo-Apollonios von Tyana (Berlin: de Gruyter 1980).

Wilpert, P. (ed.), Nicolai de Cusa Opera omnia. IV. Opuscula. 1. De Deo abscondito, De quaerendo Deum, De filiatione Dei, De dato patris luminum, Coniectura de ultimis diebus, De genesi (Hamburg: Meiner 1959).

Wlosok, A., Laktanz und die philosophische Gnosis: Untersuchungen zu Geschichte und Terminologie der gnostischen Erlösungsvorstellung (Heidelberg: Winter 1960).

Wuensch, R. (ed.), Ioannis Lydi liber de mensibus (Stuttgart: Teubner 1967).

Zieliński, T., Hermes Trzykroć-Wielki (Hermes Trismegistos). Studium z cyklu: Wspótzawodnicy chrześcijaństwa (Zamość: Pomarański 1921).

Zosime de Panopolis, Les alchimistes grecs. IV/1. Mémoires authentiques (text and trans. M. Mertens) (Paris: Belles Lettres 1995).

Zycha, J. (ed.), Sancti Aurelii Augustini De utilitate credendi; De duabus animabus; Contra Fortunatum; Contra Adimantum; Contra epistulam fundamenti; Contra Faustum (CSEL 25.6.1; Vienna: Tempsky 1891). 
